Universidad de Lima

Facultad de Comunicación

Carrera de Comunicación

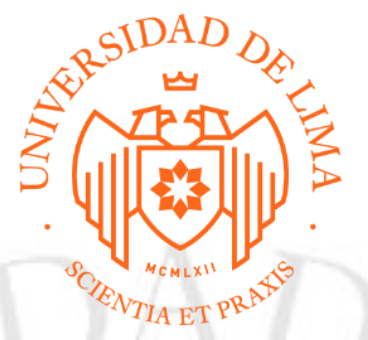

\title{
VIAJE LINDO AIRLINES: PLAN DE ACCIÓN FRENTE A LA CRISIS CORPORATIVA, CONTROL DE DAÑNOS Y PREVENCIÓN DE FUTURAS CRISIS
}

Trabajo de Suficiencia Profesional para optar el Título Profesional de Licenciado en Comunicación

\section{Dan Alberto Blas Rivera}

Código 20061385

$$
\text { Lima - Perú }
$$

septiembre de 2019 


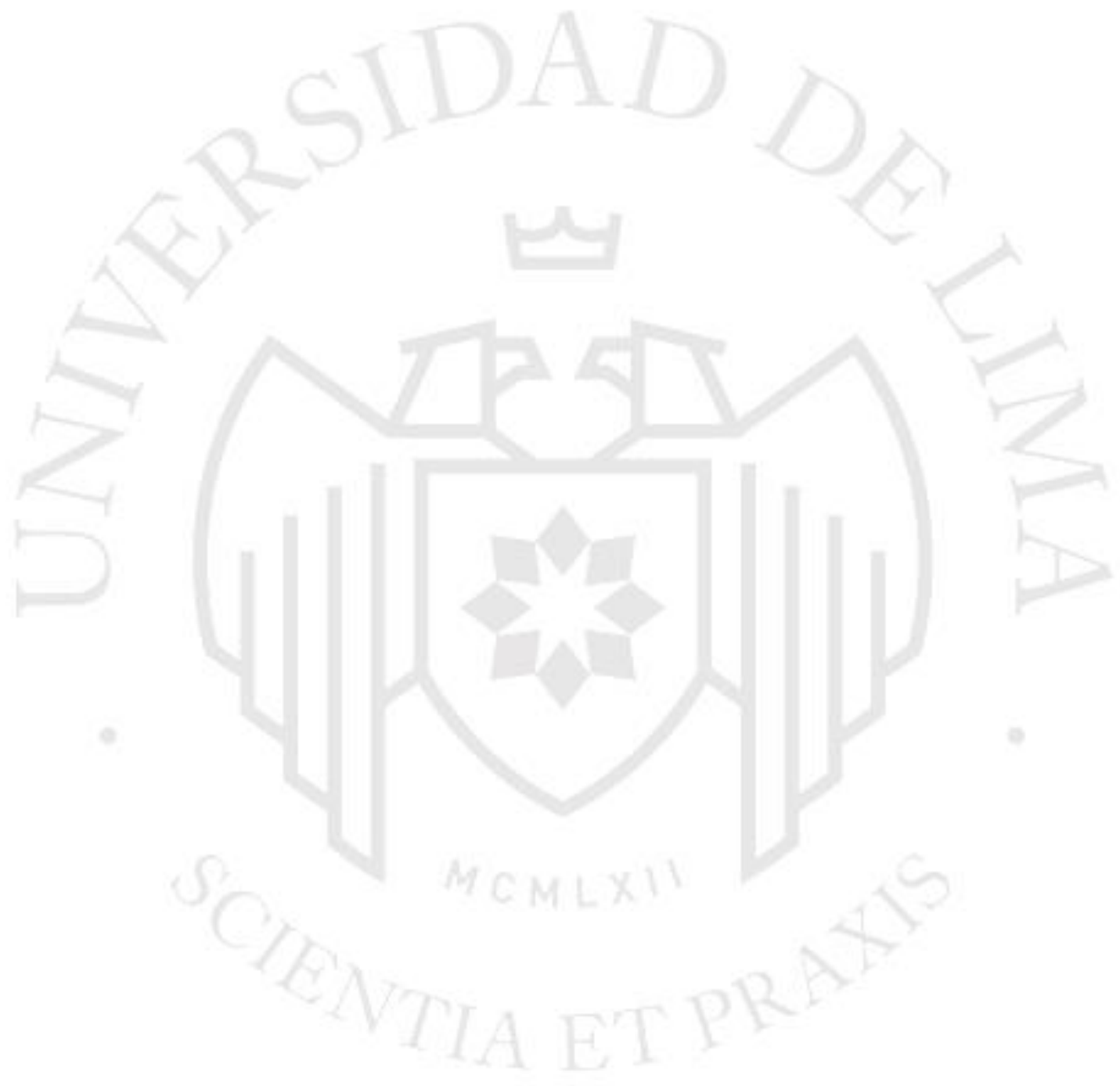




\section{VIAJE LINDO AIRLINES: PLAN DE ACCIÓN FRENTE A LA CRÍSIS CORPORATIVA, CONTROL DE DAÑOS Y PREVENCIÓN DE FUTURAS CRISIS}




\section{ÍNDICE}

RESUMEN............................................................... 10

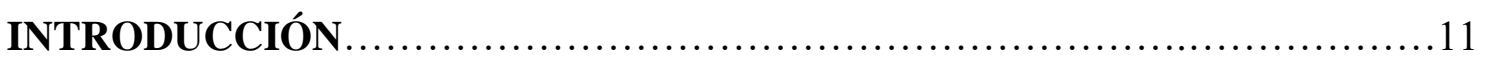

\section{ANTECEDENTES DEL TRABAJO}

1.1 Análisis del sector y contexto

1.1.1 Sector aerocomercial a nivel mundial................................12

1.1.2 Sector aerocomercial a nivel nacional...............................13

1.2 Catástrofes aéreas y reputación......................................14

1.3 Mapeo de grupos de interés.......................................... 18

1.4 Análisis DAFO empresarial.......................................21

1.5 Análisis DAFO de comunicación.....................................21

1.6 Análisis FODA cruzado............................................22

1.7 Concepto de reputación.............................................23

1.8 Concepto de responsabilidad social................................25

1.9 Concepto de posicionamiento reputacional............................26

\section{PROPUESTA DE COMUNICACIÓN}

2.1 Estructura y competencias del área de comunicación......................27

2.2 Primer objetivo de comunicación durante gestión de la crisis................30

2.2.1 Prioridad estratégica

2.2.2 Estrategia

2.2.3 Público objetivo

2.2.4 Acciones tácticas

2.2.5 Indicadores

2.2.6 Presupuesto

2.3 Segundo objetivo de comunicación durante gestión de la crisis.

2.3.1 Prioridad estratégica

2.3.2 Estrategia

2.3.3 Público objetivo

2.3.4 Acciones tácticas

2.3.5 Indicadores

2.3.6 Presupuesto 
2.4 Primer objetivo de comunicación post crisis

2.4.1 Prioridad estratégica

2.4.2 Estrategia

2.4.3 Público objetivo

2.4.4 Acciones tácticas

2.4.5 Indicadores

2.4.6 Presupuesto

2.5 Segundo objetivo de comunicación post crisis

40

2.5.1 Eje estratégico

2.5.2 Estrategia

2.5.3 Público objetivo

2.5.4 Acciones tácticas

2.5.5 Indicadores

2.5.6 Presupuesto

2.6 Tercer objetivo de comunicación post crisis

2.6.1 Eje estratégico

2.6.2 Estrategia

2.6.3 Público objetivo

2.6.4 Acciones tácticas

2.6.5 Indicadores

2.6.6 Presupuesto

2.7 Cuarto objetivo de comunicación post crisis

2.7.1 Eje estratégico

2.7.2 Estrategia

2.7.3 Público objetivo

2.7.4 Acciones tácticas

2.7.5 Indicadores

2.7.6 Presupuesto

2.8 Quinto objetivo de comunicación post crisis

2.8.1 Eje estratégico

2.8.2 Estrategia

2.8.3 Público objetivo

2.8.4 Acciones tácticas

2.8.5 Indicadores 
2.8.6 Presupuesto

2.9 Cuadro de gastos

2.9.1 Cuadro de gastos durante gestión de la crisis.......................38

2.9.2 Cuadro de gastos post crisis................................45

2.9.3 Retorno de la Inversión o ROI.................................48

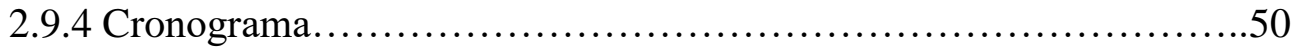

\section{SUSTENTACIÓN}

3.1 Argumentos conceptuales .....................................53

3.2 Entrevistas a especialistas..........................................54

3.3 Opinión personal........................................... 55

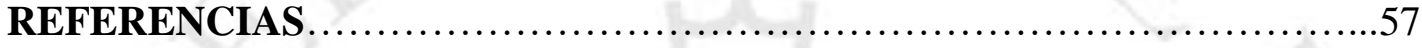

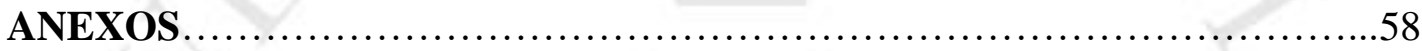


Dirección web de las piezas y producciones de comunicación parte del trabajo

https://drive.google.com/open?id=1a948KqBxuPIbT2JIN5oe7IWOhAYtCpcR 


\section{ÍNDICE DE TABLAS}

Tabla 1 La imagen y reputación corporativa como relación gestáltica................24

Tabla 2 Diferencias entre imagen y reputación corporativa.........................24 


\section{ÍNDICE DE FIGURAS}

Figura 1 Tráfico anual de pasajeros en Perú (millones).............................58

Figura 2 Tráfico anual de pasajeros por línea aérea en Perú (2010-2018) ....................58

Figura 3 Tráfico de pasajeros en Perú (enero-febrero 2019) .....................................59

Figura 4 Acciones de comunicación tomadas por la compañía.....................59

Figura 5 Punto del viraje, la ruta seguida por el MH370 y el área de búsqueda inicial.60

Figura 6 Acciones de comunicación tomadas por malaysia airlines...................60

Figura 7 Principales instrumentos internacionales de RSC.........................61 


\section{RESUMEN EN ESPAÑOL}

Las crisis empresariales son situaciones a las que están expuestas todas las empresas sin importar el giro del negocio. La diferencia entre una organización y otra es el grado de preparación que pueda tener para afrontarla. El inicio para hacer frente a la crisis empresarial es tener claro la conformación del comité de crisis y sus respectivas funciones. En el caso de las aerolíneas los accidentes son temas sensibles y de alta exposición mediática. Un ejercicio que debe realizar toda empresa es la elaboración de su plan de crisis, para lo cual puede contratar una empresa externa para su creación, sin embargo necesariamente se necesita del compromiso de los líderes de la organización. En el presente trabajo se toman en cuenta la reputación como pilar importante a proteger y el posicionamiento de la compañía. En la segunda parte del trabajo se tiene como prioridad la capitalización y prevención de futuras crisis.

Las estrategias y acciones usadas en el presente trabajo están ligadas a conceptos de reputación, responsabilidad social empresarial o corporativa, posicionamiento corporativo, media training, sector aerocomercial.

\section{Palabras clave:}

Reputación, responsabilidad social empresarial o corporativa, posicionamiento corporativo, media training, sector aerocomercial.

\section{RESUMEN EN INGLÉS}

Business crises are situations to which all companies are exposed regardless of the business. The difference between one organization and another is the degree of preparation that you may have to face it. The beginning to deal with the business crisis is to be clear about the formation of the crisis committee and its respective functions. In the case of airlines, accidents are sensitive issues with high media exposure. An exercise that every company must carry out is the elaboration of its crisis plan, for which it can hire an external company for its creation. However the commitment of the leaders of the organization is necessarily needed. In this work, reputation as an important pillar to protect and the positioning of the company are taken into account. In the second part of the work, capitalization and prevention of future crises is a priority. The strategies and actions used in this work are linked to concepts of reputation, corporate or corporate social responsibility, corporate positioning, media training, air commercial.

\section{Keywords:}

Reputation, corporate social responsibility, corporate positioning, media training, air commercial. 


\section{INTRODUCCIÓN}

La crisis corporativa o empresarial es una de las peores situaciones que una organización puede pasar. Es el periodo de tiempo en que la empresa se ve expuesta ante las luces de la opinión pública, y los grupos de interés se encuentran expectantes de saber cuál será la situación en la que termine.

En el mundo de los negocios ninguna empresa es ajena a sufrir de crisis corporativa o empresarial, sin embargo si la organización se encuentra preparada para afrontarla es más probable que salga airosa de está difícil situación.

Los indicados y llamados a afrontar las crisis son los Directores de Comunicación, también llamados Dircom o los responsables de comunicación, junto al comité de crisis. Para lo cual tienen que definir estrategias que reduzcan los daños y puedan salir rápido de la situación de crisis.

El presente Plan de Acción frente a la crisis corporativa de Viaje Lindo Airlines busca restablecer a la empresa al estado anterior a la crisis e incluso salir de la crisis mejor posicionados, a su vez controlar los daños y prevenir futuras crisis. 


\section{ANTECEDENTES DEL TRABAJO}

\section{PARTE 1}

\section{ANÁLISIS DEL SECTOR Y CONTEXTO}

\subsection{Sector aerocomercial a nivel mundial}

El sector aerocomercial mundial maneja cifras que se calculan en miles de millones de dólares. Las estadísticas proyectadas llegarán a los \$885,000 millones el 2019, cifra que superará en $7.7 \%$ en comparación al año 2018 (IATA) ${ }^{1}$. Esta misma asociación destaca que 4590 millones de pasajeros se desplazarán por el mundo en el periodo 2019, contra los 4340 millones de pasajeros del año 2018. Si se toma en cuenta que la población aproximada en el mundo para el año 2015 ha sido de 7300 millones de personas (ONU) ${ }^{2}$. El número de viajes proyectadas para el presente año resulta una cifra exorbitante, claro está que muchos de esos pasajeros son viajeros frecuentes, ya que el costo de un ticket de avión, aún es restrictivo para un sector de la población en muchos países del mundo.

Existen variables que ayudarán al crecimiento en la aviación comercial y estos son: La proyección del crecimiento mundial del PBI (Producto Bruto Interno) en un $3,1 \%$ el presente año. $\mathrm{Si}$ bien menor un $0,1 \%$ al año anterior, aún significativo. Otro factor es el costo del barril de petróleo en $\$ 65$ en promedio. También el crecimiento de la demanda de pasajeros en $6 \%$ el 2019, entre otros.

"Nunca ha sido más fácil viajar. Además de disponer de tarifas muy económicas, los viajeros cuentan con una oferta cada vez mayor de destinos. En 2018 se abrieron cerca de 1.300 conexiones directas nuevas y se realizaron 250 millones de viajes aéreos más que en 2017', De Juniac (Director General y CEO de IATA).

En relación a Latinoamérica se proyecta un beneficio neto de $\$ 700$ millones de dólares para el año 2019, cifra superior en \$300 millones de dólares al año anterior.

$\mathrm{Al}$ igual que en Europa con Ryanair o EasyJet que son serios competidores. La tendencia en el mercado Latinoamericano es la prominencia de las aerolíneas low cost (a bajo costo) que ya dominan el mercado mexicano y brasileño en cantidad de pasajeros frente a las aerolíneas tradicionales.

\footnotetext{
1 Fuente: Asociación de Transporte Aéreo Internacional o en inglés International Air Transport Association (IATA). https://www.iata.org/pressroom/pr/Documents/2018-12-12-01-sp.pdf

2 Tomado de https://www.un.org/es/sections/issues-depth/population/index.html
} 
En Brasil la empresa Gol y Azul Linhas Aéreas, ambas aerolíneas low cost dominan el mercado aerocomercial de Brasil con el 62,1\% dejando al grupo Latam con el $31,5 \%$ del mercado ${ }^{3}$.

En México la aerolínea low cost Volaris se convirtió en la primera, en cuanto a pasajeros transportados en comparación a Aeroméxico con $31 \%$ y $25 \%$ respectivamente.

En Argentina, Chile y Colombia tienen una cuota de mercado del 40\%, 30\% y $14 \%$ respectivamente.

El mercado aerocomercial en el mundo y en Latinoamérica es muy competitivo y cambiante. Para muestra, la empresa colombiana Avianca Brasil se declaró en quiebra en diciembre del 2018 y en mayo de 2019 dejó de volar.

\subsection{Sector aerocomercial a nivel nacional}

La evolución del tráfico anual de pasajeros en el país desde el año 2010 ha estado en alza constante (Figura 1) y el año 2018 se cerró con más de 12 millones.

El mercado peruano de aviación comercial ha cambiado en relación al año anterior. Los participantes y sus cuotas de mercado se reconfiguró. Esto debido a la salida del mercado de la aerolínea LCPerú en noviembre del año 2018, luego de que la Dirección General de Aeronáutica Civil ${ }^{4}$ (DGAC) suspendiera sus operaciones. El transporte que realizó LCPerú el año anterior fue de 1, 004,952 pasajeros (Figura 2), lo que deja todo este mercado para ser aprovechado por otras aerolíneas.

La más beneficiada hasta el momento es la empresa low cost Viva Air que ingresó al mercado peruano el año 2017. Entre los meses de enero a febrero 2019, obtuvo el $12.67 \%$ del mercado (Figura 3) lo que representa 257,061 pasajeros transportados ${ }^{5}$. Esta misma empresa el año 2018 transportó 797,837 pasajeros, es decir, si la empresa continuó con las mismas proyecciones en tan sólo 3 meses la empresa alcanzaría 771,183 pasajeros transportados, cantidad casi similar al número de pasajeros que transportaron en todo el año 2018

\footnotetext{
${ }^{3}$ Fuente AEROLATIN News http://aerolatinnews.com/destacado/las-low-cost-ya-dominan-el-mercadodomestico-en-brasil-y-mexico/

${ }^{4}$ Es un órgano de línea de ámbito nacional que ejerce la Autoridad Aeronáutica Civil en el Perú y se encarga de fomentar, regular y administrar el desarrollo de las actividades del transporte aéreo así la navegación aérea civil dentro de nuestro territorio y en sujeción a la legislación aeronáutica del Perú, anexos y documentos de la Organización de Aviación Civil Internacional (OACI), así como Regulaciones Aeronáuticas Peruanas (RAP). Fuente página MTC.

${ }^{5}$ Fuente DGAC
} 
Otra empresa que ingresó al mercado peruano fue la aerolínea chilena Sky Airline con el concepto low cost. El CEO de esta empresa José Raúl Vargas, señala que tiene estimaciones de transportar a 900,000 pasajeros el 2019 lo que captaría el $10 \%$ el mercado.

Una de las más dañadas por esta guerra de precios que se ha batallado este año ha sido la aerolínea Avianca. A la fecha Avianca en el mercado interno sólo opera en la ruta Lima-Cusco, y en palabras del director de Avianca Perú, Nissim Jabiles estarán satisfechos si se quedan con el 5\% del mercado, cifra casi $4 \%$ menor al año $2018^{6}$

\section{Catástrofes aéreas y reputación}

Las crisis empresariales son circunstancias que ponen en peligro la salud o la vida del negocio (Remy 2018) y un accidente o incidente aéreo hace que las luces de la prensa se enfoquen en la aerolínea y la escudriñen.

Las razones de los accidentes pueden ser por fallo humano, mecánico, problemas climatológicos, entre otros. Siendo la principal el error humano.

A pesar que las palabras accidentes e incidentes puedan parecer iguales. La Organización de Aviación Civil Internacional (OACI) en su anexo 13 y capítulo I la define de la siguiente manera ${ }^{7}$ :

Accidente. Todo suceso relacionado con la utilización de una aeronave, que, en el caso de una aeronave tripulada, ocurre entre el momento en que una persona entra a bordo de la aeronave, con la intención de realizar un vuelo, y el momento en que todas las personas han desembarcado, o en el caso de una aeronave no tripulada, que ocurre entre el momento en que la aeronave está lista para desplazarse con el propósito de realizar un vuelo y el momento en que se detiene, al finalizar el vuelo, y se apaga su sistema de propulsión principal, durante el cual:

\section{a) Cualquier persona sufre lesiones mortales o graves a consecuencia de:}

hallarse en la aeronave, o por contacto directo con cualquier parte de la aeronave, incluso las partes que se hayan desprendido de la aeronave, o por exposición directa al chorro de un reactor, excepto cuando las lesiones obedezcan a causas naturales, se las haya causado una persona a sí misma o hayan sido causadas por otras personas o se trate de lesiones sufridas por pasajeros clandestinos

\footnotetext{
6 Tomado de https://elcomercio.pe/economia/dia-1/aerolineas-reconfigura-ranking-lideres-boom-lowcost-latam-avianca-viva-air-sky-airline-noticia-634694

${ }^{7}$ Tomado de https://desdelacabinadevuelo.com/2014/01/29/diferencia-entre-accidente-e-incidente-aereo/
} 
escondidos fuera de las áreas destinadas normalmente a los pasajeros y la tripulación; o

b) La aeronave sufre daños o roturas estructurales que: afectan adversamente su resistencia estructural, su performance o sus características de vuelo; y que normalmente exigen una reparación importante o el recambio del componente afectado, excepto por falla o daños del motor, cuando el daño se limita a un solo motor (incluido su capó o sus accesorios); hélices, extremos de ala, antenas, sondas, álabes, neumáticos, frenos, ruedas, carenas, paneles, puertas de tren de aterrizaje, parabrisas, revestimiento de la aeronave (como pequeñas abolladuras o perforaciones), o por daños a álabes del rotor principal, álabes del rotor compensador, tren de aterrizaje y a los que resulten de granizo o choques con aves (incluyendo perforaciones en el radomo) o

\section{c) la aeronave desaparece o es totalmente inaccesible.}

Incidente. Todo suceso relacionado con la utilización de una aeronave, que no llegue a ser un accidente, que afecte o pueda afectar la seguridad de las operaciones.

Incidente grave. Un incidente en el que intervienen circunstancias que indican que hubo una alta probabilidad de que ocurriera un accidente, que está relacionado con la utilización de una aeronave y que, en el caso de una aeronave tripulada, ocurre entre el momento en que una persona entra a bordo de la aeronave, con la intención de realizar un vuelo, y el momento en que todas las personas han desembarcado, o en el caso de una aeronave no tripulada, que ocurre entre el momento en que la aeronave está lista para desplazarse con el propósito de realizar un vuelo y el momento en que se detiene, al finalizar el vuelo, y se apaga su sistema de propulsión principal.

Después de tener una definición clara. Los accidentes están ligados con lesiones mortales o graves consecuencias de personas al encontrase en la aeronave, a causa de daños o roturas estructurales de la aeronave, también se llama cuando la aeronave desaparece como el caso del vuelo 370 de Malaysia Airlines.

\section{Caso germanwings:}

El 24 de marzo de 2015 el avión 4U9525 de la empresa germanwings (low cost), subsidiaría de la empresa alemana Lufthansa, parte del aeropuerto de El Prat, Barcelona con destino a Düsseldorf y se estrelló en los Alpes franceses (Barcelonnette) dejando 150 personas fallecidas o desaparecidas. 
Las causas del accidente a bordo del Airbus A320 se debieron a la caída del avión originado por el copiloto alemán Andreas Günter Lubitz, quien aparentemente sufría problemas psicológicos.

\section{Respuesta de la empresa ${ }^{8}$ :}

1) El mismo día de la tragedia los CEO de Lufthansa y germanwings Casten Spohr y Thomas Winkelman realizaron ruedas de prensa para informar la situación del accidente y mostraron apertura a las preguntas de los medios de comunicación.

2) Logo de germanwings teñido de negro en señal de duelo, además retira el número de vuelo.

3) Lufthansa incorpora en su web un apartado de condolencias.

4) Carsten Spohr CEO de Lufthansa, visitó la zona 8 días después del accidente y pidió disculpas.

5) La aerolínea utilizó Twitter como canal para difundir los comunicados de prensa.

6) Difundió la etiqueta (hashtag) \#indeepsorrow

7) El CEO de Lufthansa lanza mensaje en vídeo, después de 24 horas del accidente.

8) Lufthansa utilizó las redes sociales para solidarizarse con los familiares de las víctimas del siniestro y cambiaron sus cuentas a tonos grises en señal de luto.

\section{Amenaza a la reputación:}

1) La caída de la web por exceso de tráfico (El no tener la información oficial de la empresa en este canal de comunicación crea zozobra y genera el efecto contrario a lo que se busca, que es generar tranquilidad a los familiares de las víctimas).

2) Aparición de fotografías falsas del accidente.

La empresa se mostró empática con los familiares de las víctimas y mandó ese mensaje a la sociedad (Figura 4). Si bien después de una tragedia los familiares de las víctimas están en estado de dolor, unas disculpas sinceras de los líderes de la empresa puede reducir el daño a la reputación, siempre que la empresa no se haya envuelto en sucesos similares de manera seguida, y esas disculpas se tomen por la sociedad de forma genuina y no como obligación.

\section{Caso Malasya Airlines:}

El vuelo MH370 de Malaysia Airlines, un Boeing 777 despegó a las 12.42 de la madrugada del 8 de marzo de 2014 de Kuala Lumpur, en Malasia con destino a Pekín. El vuelo estaba bajo el mando del capitán Zaharie Ahmad Shah, un piloto de 53 años, y su copiloto era Fariq Hamid. La mayoría de los que murieron en

\footnotetext{
${ }^{8}$ Estudio de Logic Activity
} 
ese accidente eran ciudadanos chinos. El cambió de curso del avión (Figura 5) y otras razones hacen presumir a los investigadores que el responsable del accidente fue el piloto.

\section{Respuesta de la empresa9:}

1) La aerolínea emitió comunicados.

2) Habilitó un teléfono de contacto para los afectados y un correo electrónico. Asimismo puso un número de contacto para medios de comunicación.

3) Habilitó un dark site dentro de su web con información actualizada.

4) Organizaron una rueda de prensa al día siguiente de la desaparición.

5) Retiró los códigos de vuelo MH370 como muestra de respeto.

6) Cambio de la foto de portada de Facebook.

7) Mensajes en Facebook y Twitter.

8) Actualización de medios sociales entre 3 y 4 veces al día en los primeros días.

\section{Amenaza a la reputación:}

1) Críticas por versiones diferentes sobre la última conversación con la torre de control.

2) Rectificación de comunicados.

3) Falta de coordinación

En la vida diaria, como en cualquier actividad empresarial la veracidad y certeza de lo que se dice (informa) juega un rol sustancial en la credibilidad de quién lo dice, es por ello que en esta tragedia la rectificación de comunicados, al igual que la falta de coordinación juegan en contra de la empresa. Pero sin duda es mejor rectificarse y decir la verdad, a quedarse callados y que la prensa se entere que lo que se dijo no es verdadero.

La influencia que cumplen las redes sociales en la vida en sociedad desde hace 10 años va en aumento, y con ello, también cambia la comunicación dirigido a los públicos a través de estos canales de comunicación. Esta imagen (Figura 6) muestra las acciones en redes sociales que hizo la empresa en redes sociales.

\section{Caso Pan American World Airways (Pan Am):}

La historia de Pan Am comienza con la fundación de la empresa por Juan Terry Trippe. El primer vuelo de Pan Am se realizó de Key West (Cayo Hueso) Florida hacia La Habana - Cuba, el 19 de octubre de 1927.

Cuando se habla de la historia de la aviación, Pan Am tiene un lugar especial, pues simbolizaba el glamour, cosmopolitismo, status. Para algunos, lo pueden llamar la era dorada de la aviación. Esta aerolínea alcanzó a unir 225 destinos en 86 países.

\footnotetext{
${ }^{9}$ Estudio de Logic Activity
} 
La crisis energética del año 1973 causó un fuerte impacto en los costos operacionales de Pan Am, además de otros factores que fueron agravando con el tiempo su situación financiera.

El 21 de diciembre de 1988, un atentado terrorista hizo explotar el avión de Londres a Nueva York de la aerolínea Pan Am sobre la localidad escocesa de Lockerbie, que dejó 270 personas fallecidas.

La mala estrategia de comunicación frente al atentado terrorista fue la cereza de la torta, puesto que la situación financiera de Pan Am no era auspiciosa. Después de algunos años se declaró en bancarrota.

\section{Respuesta de la empresa:}

1) Negar que el accidente haya sido a causa de un atentado terrorista.

2) Negar que existieran fallos en la seguridad de la aerolínea.

3) Después tuvieron que aceptar que el avión explotó a causa de un atentado terrorista.

Al hacer una mirada en retrospectiva, una buena estrategia de comunicación hubiera sido mostrarse como los "abanderados" contra el terrorismo. Que ninguna situación de terror iba a parar los viajes y la vida cotidiana de la gente. Incluso el gobierno de Estados Unidos lo pudiera haber ayudado.

Pero la primera acción que tenía que decir Pan Am para que la estrategia antes señalada funcione, era decir solamente la verdad.

La enseñanza que esta tragedia nos deja es que es mejor decir la verdad y darle un enfoque positivo a nuestro favor, que tratar de ocultar la verdad a la prensa.

\section{Mapeo de grupos de interés}

Se entiende por stakeholder a cualquier individuo o grupo de interés que afecta de manera directa o indirecta la puesta en marcha de la empresa, es decir el normal funcionamiento y operación. En otras palabras cualquier grupo o individuo que afecta o es afectado con los objetivos empresariales (Freeman, 1984, 24).

Cuando nos referimos a los stakeholder solamente como el individuo o grupo de personas que pueden obstaculizar el normal funcionamiento de la empresa nos limitamos y no le damos la mirada a largo plazo que necesita este concepto.

La esencia para construir relaciones sólidas y a futuro con nuestros grupos de interés es que estos, también cumplan con sus objetivos, de acuerdo a la posición en la que se encuentren, es decir, los accionistas reciban utilidades, que el estado reciba los impuestos y este conforme con el actuar empresarial como fiscalizador 
de sus operaciones, que la comunidad no se vea perjudicada por la contaminación sonora, lumínica, ambiental, etc. que puedan causar en sus actividades como empresa. En resumidas cuentas que todos los grupos de interés obtengan los máximos beneficios para tener una sólida relación a futuro.

\begin{tabular}{|c|c|}
\hline Grupos de interés & Expectativas y necesidades \\
\hline $\begin{array}{l}\text { Accionistas } \\
\text { El accionista mayoritario y gerente } \\
\text { general es la figura más importante, } \\
\text { entre otros accionistas minoritarios. }\end{array}$ & $\begin{array}{l}\text { A los accionistas vistos como } \\
\text { inversores les motiva los beneficios } \\
\text { económicos (utilidades) que le puede } \\
\text { dar la empresa. Sin embargo se } \\
\text { aprecia que estos accionistas están } \\
\text { comprometidos con el uso de } \\
\text { biocombustible, es decir con la } \\
\text { sostenibilidad del negocio a largo } \\
\text { plazo. }\end{array}$ \\
\hline $\begin{array}{l}\text { Colaboradores Alta directiva, área } \\
\text { de comunicaciones, legal, } \\
\text { administración, finanzas, operaciones, } \\
\text { recursos humanos, pilotos de avión, } \\
\text { aeromozas, mandos medios y otros } \\
\text { colaboradores que trabajan para la } \\
\text { empresa. }\end{array}$ & $\begin{array}{l}\text { Los colaboradores de acuerdo a su } \\
\text { cultura corporativa tienen presente el } \\
\text { cuidado del medio ambiente y buscan } \\
\text { un reconocimiento o incentivo por su } \\
\text { trabajo. }\end{array}$ \\
\hline Proveedor: Boeing & $\begin{array}{l}\text { La empresa Boeing como principal } \\
\text { proveedor de aviones de Viaje Lindo } \\
\text { Airlines (VLA) busca consolidar su } \\
\text { relación y aumentar sus ventas. }\end{array}$ \\
\hline $\begin{array}{l}\text { Proveedores: (Empresas peruanas } \\
\text { que le brindan servicio a VLA). }\end{array}$ & $\begin{array}{l}\text { La principal expectativa de los } \\
\text { proveedores de productos y servicios } \\
\text { de VLA en el Perú es que siga } \\
\text { creciendo para que sus ventas también } \\
\text { lo hagan, cualquier crisis en VLA } \\
\text { también los afecta económicamente. }\end{array}$ \\
\hline $\begin{array}{l}\text { Clientes: Está compuesta por los } \\
\text { clientes actuales y potenciales. }\end{array}$ & $\begin{array}{l}\text { Los clientes buscan ofertas y obtener } \\
\text { la misma calidad de servicio que si no } \\
\text { fuera una oferta. }\end{array}$ \\
\hline $\begin{array}{l}\text { Familiares de clientes } \\
\text { Este grupo lo integran los familiares } \\
\text { directos, amigos y personas que } \\
\text { simpatizan con ellos. }\end{array}$ & $\begin{array}{l}\text { En caso de incidentes o accidentes } \\
\text { ellos son los más interesados por } \\
\text { obtener información oportuna, precisa } \\
\text { y veraz sobre la situación actual de sus } \\
\text { seres queridos. }\end{array}$ \\
\hline
\end{tabular}




\begin{tabular}{|c|c|}
\hline $\begin{array}{l}\text { Ministerio de Transportes y } \\
\text { Comunicaciones } \\
\text { Es la entidad del estado que tiene bajo } \\
\text { su mando lo concerniente al tema de } \\
\text { transportes y comunicaciones. }\end{array}$ & $\begin{array}{l}\text { El MTC busca ser percibido como } \\
\text { impulsor y facilitador de sistemas de } \\
\text { transporte y comunicaciones } \\
\text { eficientes, seguros y competitivos, que } \\
\text { contribuyen a la inclusión social, la } \\
\text { integración y del desarrollo } \\
\text { económico sostenible del país. }\end{array}$ \\
\hline $\begin{array}{l}\text { Ministerio del Ambiente } \\
\text { Entidad del estado que regula } \\
\text { acciones para el cuidado del medio } \\
\text { ambiente y el buen aprovechamiento } \\
\text { de los recursos naturales. }\end{array}$ & $\begin{array}{l}\text { El Minam busca aportar en la } \\
\text { percepción de que se vea al Perú como } \\
\text { país moderno que aprovecha de forma } \\
\text { sostenible sus recursos naturales, } \\
\text { conciliando el desarrollo económico } \\
\text { con la sostenibilidad ambiental en } \\
\text { beneficio de sus ciudadanos. }\end{array}$ \\
\hline $\begin{array}{l}\text { Empresa aeroportuaria (LAP) } \\
\text { Empresa concesionario de origen } \\
\text { alemán }\end{array}$ & $\begin{array}{l}\text { La empresa aeroportuaria busca } \\
\text { mostrarse como eficiente, segura y de } \\
\text { buen servicio a los pasajeros. }\end{array}$ \\
\hline $\begin{array}{l}\text { Gobierno } \\
\text { Periodo de gobierno del 2016-202 } \\
\text { salvo cambios coyunturales. }\end{array}$ & $\begin{array}{l}\text { El gobierno tiene la necesidad de que } \\
\text { sea visto por la población como } \\
\text { defensor de los derechos de la gente y } \\
\text { que pone orden en la sociedad. }\end{array}$ \\
\hline $\begin{array}{l}\text { Comisión de Inve } \\
\text { Accidentes de Av } \\
\text { Comisión que per }\end{array}$ & $\begin{array}{l}\text { La CIAA es situaciones de accidentes } \\
\text { debe ser percibida como profesional y } \\
\text { hará lo posible por quedar bien ante } \\
\text { las cámaras. }\end{array}$ \\
\hline $\begin{array}{l}\text { Dirección General de Aeronáutica } \\
\text { Civil (DGAC) } \\
\text { Dirección que pertenece al MTC. }\end{array}$ & $\begin{array}{l}\text { Necesita ser percibida como la } \\
\text { Autoridad Aeronáutica Civil en el } \\
\text { Perú de manera sólida y confiable que } \\
\text { se encarga de fomentar, regular y } \\
\text { administrar el desarrollo de las } \\
\text { actividades del transporte aéreo así } \\
\text { como la navegación aérea civil dentro } \\
\text { de nuestro territorio. }\end{array}$ \\
\hline $\begin{array}{l}\text { Medios de comunicación } \\
\text { Están incluidos los medios } \\
\text { televisivos, radiales, escritos y } \\
\text { digitales. }\end{array}$ & $\begin{array}{l}\text { Los medios de comunicación viven de } \\
\text { la novedad y cuando una noticia deja } \\
\text { de serla le van quitando visibilidad. } \\
\text { Necesitan encontrar información } \\
\text { nueva. }\end{array}$ \\
\hline $\begin{array}{l}\text { Competencia } \\
\text { En esta se encuentra un serio } \\
\text { competidor y dos competidores } \\
\text { menores }\end{array}$ & $\begin{array}{l}\text { La competencia busca obtener la cuota } \\
\text { de mercado de VLA y aprovechará } \\
\text { cualquier debilidad que tenga para } \\
\text { tomarla. }\end{array}$ \\
\hline
\end{tabular}




\begin{tabular}{|l|l|}
\hline Aseguradora & $\begin{array}{l}\text { Ser percibida por la empresa } \\
\text { contratante como la mejor opción a } \\
\text { corto, mediano y largo plazo. }\end{array}$ \\
\hline
\end{tabular}

\section{Análisis DAFO empresarial}

\begin{tabular}{|c|c|}
\hline \multicolumn{2}{|c|}{ Viaje Lindo Airlines (VLA) } \\
\hline Fortalezas & Amenazas \\
\hline $\begin{array}{c}\text { Liquidez o ingresos suficientes para } \\
\text { adquirir nuevos aviones (Respaldo } \\
\text { financiero) }\end{array}$ & Ingreso de aerolíneas low cost \\
\hline $\begin{array}{l}\text { Preocupación por el impacto } \\
\text { medioambiental }\end{array}$ & Ataques terroristas, accidentes aéreos \\
\hline Oportunidades & Debilidades \\
\hline $\begin{array}{c}\text { Crecimiento del mercado } \\
\text { aerocomercial }\end{array}$ & $\begin{array}{c}\text { Sobrecarga laboral y descontento } \\
\text { laboral }\end{array}$ \\
\hline Alto nivel de competitividad & $\begin{array}{c}\text { Falta de confianza en los planes a } \\
\text { mediano y largo plazo de los } \\
\text { responsables de comunicación }\end{array}$ \\
\hline
\end{tabular}

\section{Análisis DAFO de Comunicación}

\begin{tabular}{|c|c|}
\hline \multicolumn{2}{|c|}{ Viaje Lindo Airlines (VLA) } \\
\hline Fortalezas & Amenazas \\
\hline $\begin{array}{c}\text { Promesa de marca "Puntualidad" } \\
\text { diferenciador frente a la competencia }\end{array}$ & Poca inversión publicitaria \\
\hline $\begin{array}{c}\text { Uso de las redes sociales como: } \\
\text { Facebook (Fanpage), Twitter, } \\
\text { Instagram, Linkedln y aplicación } \\
\text { (App) }\end{array}$ & $\begin{array}{c}\text { Disminución de la marca empleador lo } \\
\text { que conlleva a la salida de } \\
\text { colaboradores talentosos }\end{array}$ \\
\hline $\begin{array}{c}\text { Área de Responsabilidad Social } \\
\text { Empresarial (RSE) }\end{array}$ & $\begin{array}{c}\text { Que el valor de "Seguridad" sea } \\
\text { afectado (24 años sin accidentes). }\end{array}$ \\
\hline Oportunidades & Debilidades \\
\hline Capitalizar la peruanidad de la \\
empresa & $\begin{array}{c}\text { Frecuente cambio de los responsables } \\
\text { de comunicación }\end{array}$ \\
\hline $\begin{array}{c}\text { Informar al público interno y externo } \\
\text { sobre los premios y reconocimientos } \\
\text { obtenidos por las campañas de } \\
\text { sensibilidad ambiental }\end{array}$ & $\begin{array}{c}\text { Falta de centralización de los grupos de } \\
\text { Facebook y WhatsApp }\end{array}$ \\
\hline Elaborar campañas de storytelling & Deficiente canalización de la \\
\hline
\end{tabular}




\begin{tabular}{|c|c|}
\hline & información urgente e importante \\
\hline $\begin{array}{l}\text { Sacar provecho a la crisis y potenciar } \\
\text { el valor de la Seguridad externamente }\end{array}$ & $\begin{array}{c}\text { Falta de capacitación en Media training } \\
\text { de los líderes de la empresa }\end{array}$ \\
\hline $\begin{array}{l}\text { Difundir al público externo e interno } \\
\text { los reportes de GRI }\end{array}$ & $\begin{array}{l}\text { Ausencia de un Plan de crisis y un } \\
\text { Gabinete de crisis actualizado }\end{array}$ \\
\hline $\begin{array}{c}\text { Uso de Twitter y Facebook frente a } \\
\text { las crisis }\end{array}$ & $\begin{array}{l}\text { Falta de una estrategia de } \\
\text { comunicación interna }\end{array}$ \\
\hline
\end{tabular}

\section{Análisis FODA cruzado}

\begin{tabular}{|c|c|c|}
\hline \multirow{3}{*}{$\begin{array}{l}\text { FACTORES } \\
\text { EXTERNOS } \\
\text { OPORTUNIDADES }\end{array}$} & FORTALEZAS & DEBILIDADES \\
\hline & $\begin{array}{l}\text { 1. Puntualidad } \\
\text { 2. Uso de redes sociales (externas) } \\
\text { y App } \\
\text { 3. Área de RSE }\end{array}$ & $\begin{array}{l}\text { 1. Falta de centralización de los } \\
\text { grupos de Facebook y WhatsApp } \\
\text { (Internas) } \\
\text { 2. Falta de capacitación en Media } \\
\text { training de los líderes de la } \\
\text { empresa y ausencia de un plan de } \\
\text { crisis y su gabinete actualizado } \\
\text { 3. Falta de una estrategia (acciones) } \\
\text { de comunicación interna }\end{array}$ \\
\hline & & \\
\hline $\begin{array}{l}\text { 1. Informar al público } \\
\text { interno y externo sobre } \\
\text { los valores, programas } \\
\text { de RSE y sus } \\
\text { reconocimientos. } \\
\text { 2. Elaborar campañas de } \\
\text { storytelling } \\
\text { 3. Uso de Twitter y } \\
\text { Facebook frente a las } \\
\text { crisis }\end{array}$ & $\begin{array}{l}\text { 1. Comunicar al público interno y } \\
\text { externo el valor de la puntualidad } \\
\text { 2. Uso de redes sociales para } \\
\text { difundir el storytelling empresarial } \\
\text { 3. Aprovechar y generar } \\
\text { engagement en los medios } \\
\text { digitales }\end{array}$ & $\begin{array}{l}\text { 1. Unificar las redes sociales y } \\
\text { WhatsApp internas } \\
\text { 2. Capacitación en media training } \\
\text { para aprovechar las herramientas } \\
\text { tecnológicas } \\
\text { 3. Utilizar las redes sociales y otras } \\
\text { herramientas para comunicar las } \\
\text { acciones positivas que hace la } \\
\text { empresa de manera interna }\end{array}$ \\
\hline AMENAZAS & & \\
\hline $\begin{array}{l}\text { 1. Poca inversión } \\
\text { publicitaria } \\
\text { 2. Disminución de la } \\
\text { marca empleador } \\
\text { 3. Que se afecte el valor } \\
\text { de la "Seguridad" }\end{array}$ & $\begin{array}{l}\text { 1. Disminuir la falta de inversión } \\
\text { publicitaria usando redes sociales } \\
\text { 2. Utilizar las buenas acciones de } \\
\text { RSE para mantener y atraer } \\
\text { talento } \\
\text { 3. Uso de las redes sociales para } \\
\text { mantener el valor reputacional de } \\
\text { "Seguridad" }\end{array}$ & $\begin{array}{l}\text { 1. Capacitación en media training } \\
\text { de los líderes para que en } \\
\text { momentos de crisis brinden } \\
\text { confianza (seguridad) a la sociedad } \\
\text { 2. Elaborar una estrategia de } \\
\text { comunicación interna que aumente } \\
\text { la marca empleador } \\
\text { 3. Preparar a nuestros líderes para } \\
\text { futuras apariciones en medios ATL }\end{array}$ \\
\hline
\end{tabular}




\section{Concepto de reputación corporativa}

La primera definición esencial para comenzar a una aproximación más profunda de la palabra "reputación" en el ámbito corporativo es a través de la rae, y esta la define de la siguiente manera:

\section{"prestigio o estima en que son tenidos alguien o algo"}

En la lógica empresarial siempre se ha tenido presente, conseguir las máximas utilidades para los accionistas y competitividad en su oferta comercial, en la nueva lógica empresarial se añadió una variable importante y es el "equilibrio", al menos buscar llegar a este punto. Para lo cual se juntan los dos objetivos comunes en una empresa, ya mencionados, y se une el equilibrio con la relación de sus stakeholders. (Villafañe, 2004).

Es decir después de tres revoluciones industriales, la empresa sale de su papel netamente de vender productos y servicios a tomar en cuenta a sus grupos de interés. Ya no es solamente brindar productos y servicios de calidad, sino que sus grupos de interés son tomados en cuenta en las decisiones empresariales que se tomen. El valor del intangible cobra relevancia en el mundo empresarial actual. Lo que evidencia porque hay marcas que valen más por sus intangibles que por sus activos, un claro ejemplo es Coca Cola.

"La reputación puede entenderse como la expresión de esa armonía entre lo que he denominado la lógica central de la empresa, que enfatiza los resultados económico-financieros y la fortaleza de su oferta comercial, y las lógicas marginales, orientadas hacia aquellas políticas y comportamientos corporativos como la gestión del capital humano, la sostenibilidad de sus acciones, o la ya citada responsabilidad social corporativa" (p.20).

Cada vez nos vamos ciñendo más hacia el concepto de reputación y para lo cual Villafañe hace una precisión entre la dimensión conceptual y funcional. Para definir la primera se tiene que tener en cuenta la definición y los límites de su alcance.

En la primera dimensión Villafañe encuentra dos (2) ideas constantes sobre el concepto de reputación en base a consultores y académicos "La reputación es la consecuencia de una relación eficaz y comprometida con los stakeholders de la empresa; la segunda identifica la reputación con un estadio de consolidación definitiva de la imagen corporativa de esa empresa" (p.25).

En cuanto a los límites y diferencias de la definición de reputación corporativa con el concepto de imagen corporativa estos dos cuadros nos aclaran mejor sus diferencias. 


\begin{tabular}{|l|l|}
\hline \multicolumn{1}{|c|}{ Imagen Corporativa (la figura) } & \multicolumn{1}{|c|}{ Reputación corporativa (el fondo) } \\
\hline Una figura creada, cambiante & Un fondo acumulado, consolidado \\
Más coyuntural & Más duradero \\
Más fácil de hacer y cambiar & Más difícil de conseguir y también de \\
& cambiar \\
Más superficial & Más sólida, basada en \\
Se transmite a través de la oferta & comportamientos \\
\hline
\end{tabular}

Fuente: Villafañe, J. "La Buena Reputación, claves del valor intangible de las empresa"

\begin{tabular}{|l|l|}
\hline \multicolumn{1}{|c|}{ Imagen corporativa } & \multicolumn{1}{c|}{ Reputación corporativa } \\
\hline Proyecta la personalidad corporativa & $\begin{array}{l}\text { Es fruto del reconocimiento del } \\
\text { comportamiento }\end{array}$ \\
Carácter coyuntural y efectos efímeros & Carácter estructural y efectos duraderos \\
Difícil de objetivar & Verificable empíricamente \\
Genera expectativas asociadas a la & Genera valor consecuencia de la \\
oferta & respuesta \\
Se construye fuera de la organización & Se genera en el interior de la \\
& organización \\
\hline
\end{tabular}

Fuente: Villafañe, J. "La Buena Reputación, claves del valor intangible de las empresa"

Para comprender la dimensión funcional Villafañe lo define como:

"La dimensión funcional de la reputación tiene que ver con su gestión, con los aspectos procedimentales y operativos que hay que controlar para que la reputación genere valor para la empresa" (p.24).

Ya que para entender la reputación también es necesario entender otros conceptos como imagen e identidad. Para Villafañe esta última es la historia de la empresa, entendida como el comportamiento empresarial a lo largo del tiempo, el segundo componente es el proyecto empresarial vigente y como tercer componente es la cultura corporativa. Esta cultura corporativa también es fuente de la reputación y tomado en cuenta para elaborar los ranking reputacionales.

En resumen. La reputación corporativa surge de la relación entre la empresa y sus stakeholders, así como de la solidificación de la imagen que se tiene de la empresa, para luego convertirse en reputación. Sin dejar de lado la Identidad proyectada interna y externamente. Villafañe lo dice de la siguiente manera: "La Reputación corporativa es la expresión de la identidad de la organización y del reconocimiento de su comportamiento corporativo" (p.29). Para explicarlo mejor dice también lo siguiente: "La reputación tiene su origen en la realidad de la 
empresa y, más concretamente, en su historia, en la credibilidad del proyecto empresarial vigente y en la alineación de su cultura corporativa con ese proyecto" (p.30).

En conclusión lo hecho por la empresa (pasado/historia), la actuación presente de la empresa y de su credibilidad. Así como la cultura corporativa en claro alineamiento al proyecto empresarial llevan a la formación de la reputación corporativa.

En el caso de Viaje Lindo Airlines (VLA) tiene 24 años en el mercado y sin ningún tipo de incidentes o accidentes. Lo que hace que su historia empresarial sea coherente con su valor reputacional, es decir la "seguridad". El otro valor reputacional "puntualidad" también es coherente con lo que se comunica porque en los hechos VLA es la aerolínea con menos retrasos en minutos a nivel nacional.

En otras palabras lo que dice va de la mano con lo que se hace, salvo este accidente que pone a prueba a la empresa y a su reputación.

\section{Concepto de responsabilidad social empresarial}

A partir del año 1987 aparece por primera vez el concepto de "Desarrollo Sostenible" en el informe "Nuestro Futuro Común" de allí en adelante se ha escrito mucho al respecto.

El ISO 26000:2010 define a la responsabilidad social como:

"Es la responsabilidad de una organización por los impactos que sus decisiones y actividades ocasionan en la sociedad y el medioambiente, demostrando un comportamiento ético y transparente que:

- Contribuya al desarrollo sostenible.

- Tome en cuenta las expectativas de los stakeholders

- Cumpla con la legislación aplicable y las normas internacionales; y esté integrada en toda la organización".

Para el presente trabajo utilizaremos la RSC como sinónimo de RSE, aunque la primera tenga un campo de acción más amplio que incluye organizaciones que no son empresas como instituciones del estado, entre otras y que en ambos casos sus acciones van mucho más lejos de lo mínimo exigido por la ley.

Esta definición de responsabilidad social empresarial nos ayuda a entender dónde empieza la responsabilidad social empresarial: "La RSE empieza cuando la empresa cumple lo legal y excede ese marco, otorgando más beneficios a la sociedad y a los trabajadores que aquello a lo que la obliga el marco legal 
existente. La ley es el estándar mínimo que todos deben cumplir y la RSE empieza donde termina lo legal" (Solano 2009).

En este cuadro (Figura 7) nos podemos dar una idea de los principales instrumentos internacionales que se usan en RSC, uno de los más conocidos la Iniciativa de Reporte Global o en inglés Global Reporting Inicitative (GRI), también aparece el Libro Verde de la Unión Europea, y el no menos conocido el Dow Jones Sustainability Indexes.

La empresa VLA elabora ya por tercer año consecutivo su Iniciativa de Reporte Global o en inglés Global Reporting Inicitative (GRI), que es una memoria de sostenibilidad que mide y reporta el desempeño económico, social y medioambiental. Es decir, muestra transparencia en su accionar empresarial. Además, ya por tercer año utiliza biocombustible, para disminuir el impacto medioambiental, que es una de sus preocupaciones como empresa.

En conclusión se muestra de parte de VLA la voluntad y las acciones de disminuir su impacto medioambiental en su accionar empresarial lo que genera en parte de sus clientes y potenciales clientes buena imagen y en proceso de consolidación de su reputación. La empresa VLA ya tiene diez años realizando acciones de RSE lo que le brindaría un respaldo de los clientes, potenciales clientes y sociedad en general frente a la crisis que está pasando. Si la relación de VLA con sus stakeholders es positiva es más probable que salga a flote de esta crisis.

\section{Concepto de posicionamiento reputacional}

Para Villafañe el posicionamiento reputacional es: "El estado de opinión que una empresa pretende construir en la mente de sus stakeholders como resultado de una relación eficaz con ellos, orientada a satisfacer las metas contenidas en su visión reputacional" ( $p, 156)$. Esta visión reputacional es definida y formulada por la alta dirección de una organización, siguiendo a Villafañe él la define así:

"La imagen compartida por los miembros de la alta dirección, que identifica los hechos que le permitirán a la compañía alcanzar el liderazgo en reputación y los grupos de interés en los que tendrá que apoyarse para lograrlo" $(p, 156)$. Continúa con su explicación y afirma que puede darse el caso que la Visión estratégica coincida con la visión reputacional, lo que quiere decir que la visión reputacional se convierte en conductor de la gestión corporativa.

Es necesario acotar que para obtener la formulación de este posicionamiento reputacional se necesita tomar en cuenta la visión reputacional y hacer un benchmarking sectorial 
Al coincidir la visión estratégica y la visión reputacional en VLA hace que la visión reputacional guie a la aerolínea en base a estos dos valores "seguridad" y "puntualidad” y sea más sólido su horizonte.

\section{PROPUESTA DE COMUNICACIÓN}

\subsection{Estructura y competencias del área de comunicación}

La compañía Viaje Lindo Airlines cuenta con un área de Responsabilidad Social que ya tiene diez años de labores ininterrumpidas. Además se puede ver que realizan acciones de comunicación interna, externa. Sin embargo no se tienen área definidas y delimitadas de funciones.

Para que la empresa VLA pueda tener un crecimiento sostenible y ordenado es necesario que la oficina de Comunicaciones se organice y se le empodere para crear acciones que ayuden con los objetivos organizacionales.

Para lo cual se tiene propuesto la siguiente estructura por áreas:

Director de Comunicaciones (Dircom)

- Coordinador de Comunicaciones

- Jefe de Marketing

- Jefe de Comunicación Interna

- Jefe de Comunicación Externa

- Jefe de Prensa

- Jefe de RR.PP. Promoción y Eventos

- Jefe de Responsabilidad Social

- Jefe de Publicidad

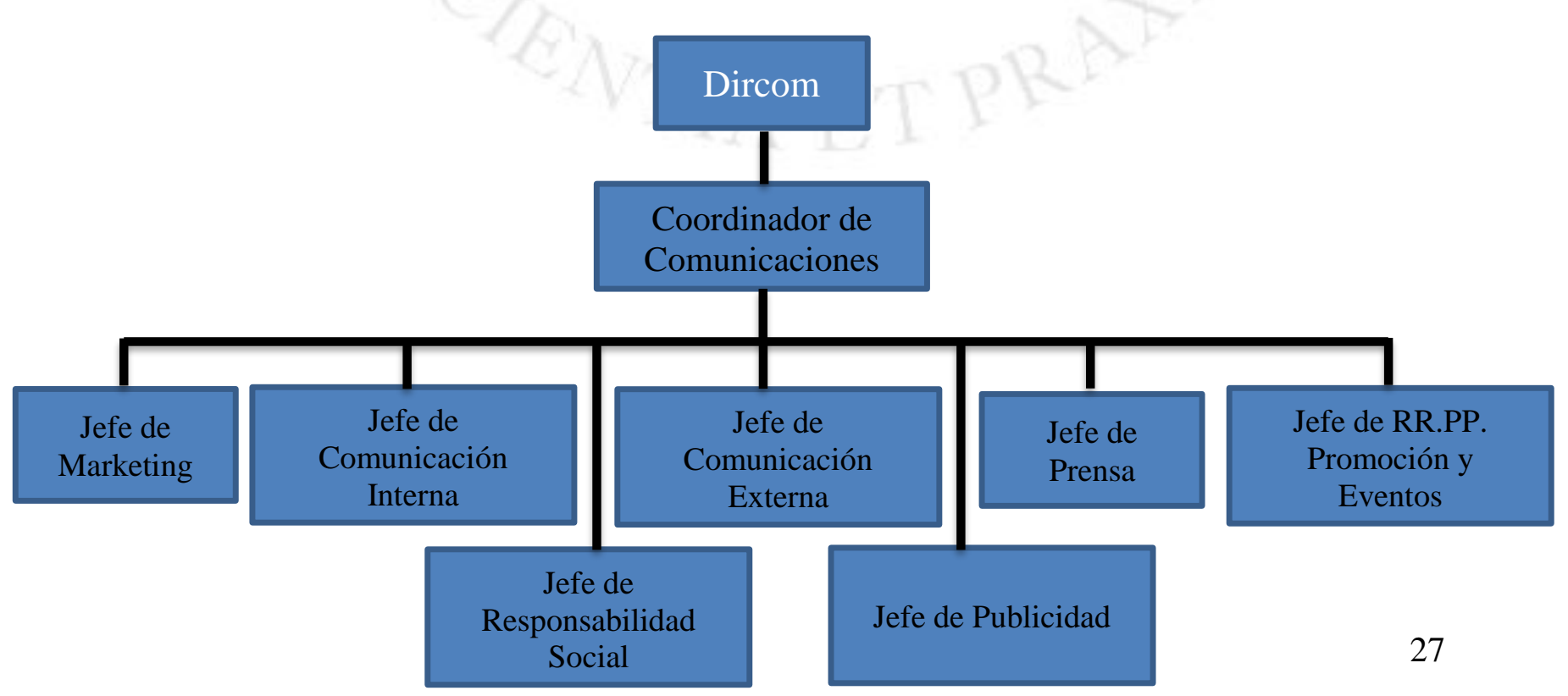


Gestión de la Crisis:

Comité de Crisis: Integrantes

\begin{tabular}{|c|c|}
\hline Cargo & Nombre \\
\hline Director General (CEO) & \\
\hline Gerente de Operaciones & \\
\hline Gerente de Finanzas & \\
\hline Gerente de Recursos Humanos & \\
\hline Gerente de Asuntos Legales & \\
\hline Gerente de Seguridad & \\
\hline Dircom (Responsable de Comunicación) & \\
\hline
\end{tabular}

Formato de comité de crisis designado:

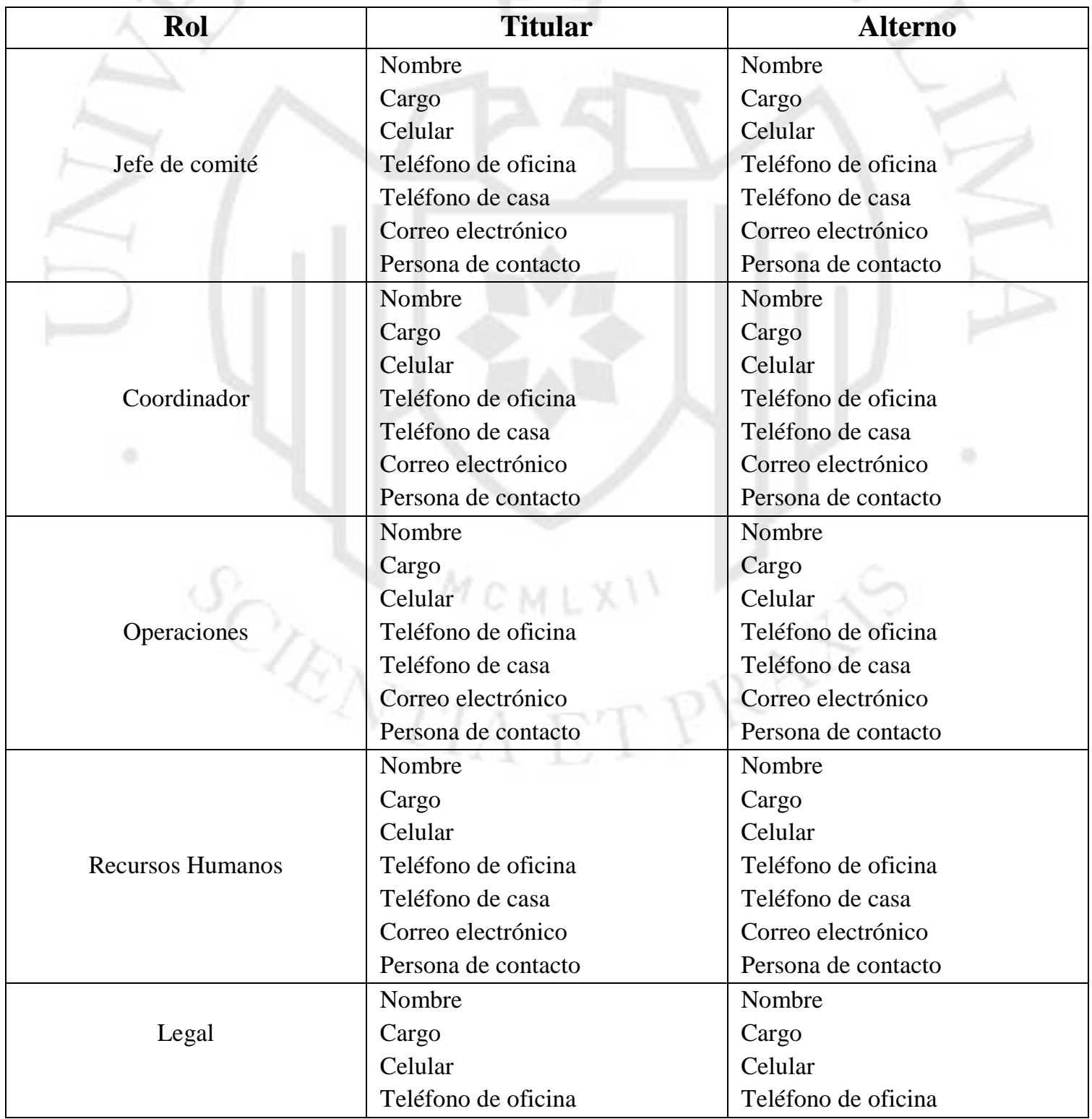




\begin{tabular}{|c|l|l|}
\hline & Teléfono de casa & Teléfono de casa \\
& Correo electrónico & Correo electrónico \\
& Persona de contacto & Persona de contacto \\
\hline & Nombre & Nombre \\
& Cargo & Cargo \\
& Celular & Celular \\
& Teléfono de oficina & Teléfono de oficina \\
& Teléfono de casa & Teléfono de casa \\
& Correo electrónico & Correo electrónico \\
& Persona de contacto & Persona de contacto \\
\hline \multirow{5}{*}{ Vocero } & Nombre & Nombre \\
& Cargo & Cargo \\
& Celular & Celular \\
& Teléfono de oficina & Teléfono de oficina \\
& Teléfono de casa & Teléfono de casa \\
& Correo electrónico & Correo electrónico \\
& Persona de contacto & Persona de contacto \\
\hline
\end{tabular}

Fuente: Remy, Paul, (2015), Manejo de crisis: ¿Qué hacer el día en que todo está en contra nuestra?

Valores corporativos: "Seguridad" y "Puntualidad"

Posicionamiento reputacional: "Seguridad" y "Puntualidad"

Objetivo: Salvaguardar la reputación y mantener el posicionamiento de la compañía.

\section{Mensajes claves:}

1) La empresa lamenta profundamente las víctimas del accidente.

2) Viaje Lindo Airlines se encarga del aspecto económico y acompañamiento a los familiares de las víctimas.

3) La seguridad de las personas es lo primero para VLA y apoyará en las investigaciones que realicen las autoridades.

\section{Premisa:}

“La información es uno de los activos más valiosos en una empresa u organización"

A criterio propio tener la mayor cantidad de información ante una crisis y saber cómo usarla nos facilita la respuesta y pronta salida de la crisis.

$\mathrm{Al}$ tener el servicio tercerizado de un monitoreo de medios offline y online (¿Qué dicen de nosotros?) nos ahorra el $50 \%$ del trabajo, y como empresa nos enfocamos en ese $50 \%$ esencial e importante que es el cómo afrontar lo que se dice en los medios ATL o en el mundo online. 


\section{Estrategia}

- Comunicación respetuosa y empática con los diferentes públicos.

- Viaje Lindo Airlines se asegurará de que los protocolos de seguridad y sus procedimientos se cumplan y no vuelva a suceder lo ocurrido.

- Brindar todas las facilidades a las autoridades para esclarecer cuáles fueron las causas exactas del accidente.

- Viaje Lindo Airlines (VLA) emitirá una declaración de pesar a todos los amigos, miembros de la familia de todos los pasajeros y miembros de la tripulación a bordo del avión.

- La empresa compensará a los familiares de los pasajeros y miembros de la tripulación a bordo del avión y se encargará del sepelio de todos los fallecidos. Así como la atención de todos los heridos a causa del accidente.

- Reunión con el público interno (Colaboradores) y proveedores de productos y servicios de VLA para que sirvan de escudo frente a la crisis y resalten las fortalezas.

\begin{tabular}{|c|c|}
\hline $\begin{array}{l}1 \text { Objetivo de comunicación (¿Qué quiero } \\
\text { alcanzar?) }\end{array}$ & $\begin{array}{l}\text { Mostrar a los familiares de las víctimas, } \\
\text { amigos y opinión pública respeto y } \\
\text { respaldo ante el accidente }\end{array}$ \\
\hline $\begin{array}{c}\text { Prioridad Estratégica (vinculado al ámbito } \\
\text { o enfoque de acción a desarrollar las } \\
\text { acciones) }\end{array}$ & Comunicación Externa \\
\hline Estrategia (¿Cómo lo voy a alcanzar?) & $\begin{array}{l}\text { Comunicación respetuosa y empática con } \\
\text { los diferentes públicos }\end{array}$ \\
\hline Público objetivo (grupo de interés) & $\begin{array}{l}\text { El público objetivo son los familiares de } \\
\text { las víctimas, amigos y medios de } \\
\text { comunicación. }\end{array}$ \\
\hline $\begin{array}{l}\text { Acciones (matriz) tácticas (descripción de } \\
\text { las acciones) }\end{array}$ & $\begin{array}{l}\text { Acción 1: Lazo negro en las redes } \\
\text { sociales y página web } \\
\text { Acción 2: Hashtag \#Losentimos } \\
\text { \#conprofundodolor } \\
\text { Acción 3: Conferencia de Prensa }\end{array}$ \\
\hline Responsabilidad de trabajo & Área de Comunicación Externa \\
\hline Meta & $\begin{array}{l}\text { Lograr que el HT se convierta en trending } \\
\text { Topic, así como más del } 70 \% \text { de } \\
\text { comentarios sean de neutros a positivos } \\
\text { por el lazo negro y la conferencia de } \\
\text { prensa. }\end{array}$ \\
\hline & $\begin{array}{l}\text { Acción 1: Medición de tasa de } \\
\text { interacción, clicks de enlace, me gusta }\end{array}$ \\
\hline
\end{tabular}




\begin{tabular}{|l|l|}
\hline & retweets, respuestas, impresiones, \\
& seguidores, menciones, visitas al perfil. \\
& Herramienta de medición: Twitter \\
& Analitics \\
& Número de visitas, alcances e \\
impresiones, tráfico web, sistema \\
& operativo, proveedor de servicios y \\
& resolución de pantalla. \\
& Herramienta de medición: Google \\
& Analitics. \\
& Acción 2: Medición de tasa de \\
& interacción, clicks de enlace, me gusta \\
& retweets, respuestas, impresiones, \\
& seguidores, menciones, visitas al perfil. \\
Herramienta de medición: Twitter \\
Andicadores y herramientas & Analitics. \\
& Acción 3: Rebote en los medios ATL y \\
que dicen al respecto & Herramienta de medición: Press clipping, \\
& monitoreo de medios. \\
\hline Presupuesto & Acción 1: Servicio tercerizado de \\
Monitoreo de Medios \\
Acción 2: Servicio tercerizado de \\
Monitoreo de Medios \\
Acción 3: Servicio tercerizado de \\
Monitoreo de Medios \\
\hline
\end{tabular}

\begin{tabular}{|c|l|}
\hline $\begin{array}{c}2 \text { Objetivo de comunicación (¿Qué quiero } \\
\text { alcanzar?) }\end{array}$ & $\begin{array}{l}\text { Establecer un escudo contra los daños de } \\
\text { reputación con grupos de interés interno y } \\
\text { externo }\end{array}$ \\
\hline $\begin{array}{c}\text { Prioridad Estratégica (vinculado al ámbito } \\
\text { o enfoque de acción a desarrollar las } \\
\text { acciones) }\end{array}$ & \multicolumn{1}{|c|}{ Comunicación Interna y Externa } \\
\hline Estrategia (¿Cómo lo voy a alcanzar?) & $\begin{array}{l}\text { Reunión con el público interno } \\
\text { (Colaboradores) y público externo } \\
\text { (proveedores) de productos y servicios de } \\
\text { VLA para que sirvan de escudo frente a la } \\
\text { crisis y resalten las fortalezas. }\end{array}$ \\
\hline Público objetivo (grupo de interés) & $\begin{array}{l}\text { Los colaboradores de la aerolínea VLA. } \\
\text { Así también los principales proveedores } \\
\text { de productos y servicios. }\end{array}$ \\
\hline & Acción 1: Reunión del gerente de \\
\hline
\end{tabular}




\begin{tabular}{|c|c|}
\hline $\begin{array}{l}\text { Acciones (matriz) tácticas (descripción de } \\
\text { las acciones) }\end{array}$ & $\begin{array}{l}\text { recursos humanos, un representante de los } \\
\text { trabajadores y el Dircom para conocer sus } \\
\text { demandas laborales y solucionarlas. Así } \\
\text { también se vuelvan nuestros voceros en } \\
\text { redes sociales. } \\
\text { Acción 2: Reunión con proveedores de } \\
\text { productos y servicios } \\
\text { Acción 3: Reunión con los colaboradores } \\
\text { para informar la situación del día a día. }\end{array}$ \\
\hline Responsabilidad de trabajo & Área de Comunicación Interna y Externa \\
\hline & $\begin{array}{l}\text { Lograr que ambos grupos de interés nos } \\
\text { apoyen y estén de nuestro lado } \\
\text { difundiendo las acciones positivas de } \\
\text { VLA. }\end{array}$ \\
\hline Indicadores y herramientas & $\begin{array}{l}\text { Acción 1: Comentarios, likes de los } \\
\text { colaboradores en redes sociales frente a } \\
\text { sus demandas laborales y apoyo en la } \\
\text { crisis. } \\
\text { Herramienta de medición: Análisis de } \\
\text { comentarios, likes. } \\
\text { Acción 2: Difusión de mensajes de apoyo } \\
\text { a VLA en redes sociales, resaltando sus } \\
\text { acciones positivas empresariales. } \\
\text { Herramienta de medición: Análisis de } \\
\text { comentarios, likes. } \\
\text { Acción 3: Preguntas clave de nueva } \\
\text { información que estamos difundiendo } \\
\text { Herramienta de medición: Nueve } \\
\text { preguntas al azar a } 3 \text { colaboradores. }\end{array}$ \\
\hline Presupuesto & $\begin{array}{l}\text { Acción 1: Servicio tercerizado de } \\
\text { Monitoreo de Medios. } \\
\text { Acción 2: Servicio tercerizado de } \\
\text { Monitoreo de Medios. } \\
\text { Acción 3: Presupuesto propio del área. }\end{array}$ \\
\hline
\end{tabular}

\section{PLAN DE ACCIÓN:}

Día lunes 10 de junio de 2019

Reunión de directorio:

\begin{tabular}{|c|c|c|c|c|}
\hline Hora & Lugar & Participantes & $\begin{array}{c}\text { Actividad a } \\
\text { realizar }\end{array}$ & Motivo \\
\hline
\end{tabular}




\begin{tabular}{|c|c|c|c|c|}
\hline $\begin{array}{l}\text { 7:00 a.m. } \\
\text { a 8:00 } \\
\text { a.m. }\end{array}$ & $\begin{array}{l}\text { Sala de } \\
\text { reuniones del } \\
\text { directorio de } \\
\text { la empresa }\end{array}$ & $\begin{array}{c}\text { Dueño y gerente } \\
\text { general (accionista } \\
\text { mayoritario), } \\
\text { representante de } \\
\text { accionistas } \\
\text { minoritarios, gerente de } \\
\text { asuntos legales, gerente } \\
\text { de recursos humanos, } \\
\text { gerente administrativo, } \\
\text { gerente financiero, } \\
\text { gerente de operaciones } \\
\text { y el Dircom } \\
\text { (responsable de } \\
\text { comunicación) }\end{array}$ & $\begin{array}{l}\text { Reunión de } \\
\text { directorio }\end{array}$ & $\begin{array}{l}\text { Presentación del } \\
\text { Plan de gestión de } \\
\text { crisis y control de } \\
\text { daños }\end{array}$ \\
\hline
\end{tabular}

\begin{tabular}{|c|c|c|c|c|c|}
\hline Hora & $\begin{array}{c}\text { Actividad a } \\
\text { realizar }\end{array}$ & $\begin{array}{l}\text { Grupo de } \\
\text { interés }\end{array}$ & Offline & Online & Justificación \\
\hline 9:00 a.m. & $\begin{array}{c}\text { Lazo negro en } \\
\text { las redes } \\
\text { sociales y } \\
\text { página web }\end{array}$ & $\begin{array}{l}\text { Familiares y } \\
\text { medios de } \\
\text { comunicación }\end{array}$ & & $X$ & $\begin{array}{c}\text { El lazo negro } \\
\text { simboliza la } \\
\text { solidaridad, empatía } \\
\text { y estado de luto de } \\
\text { la empresa por el } \\
\text { trágico evento }\end{array}$ \\
\hline 9:30 a.m. & $\begin{array}{l}\quad \text { Hashtag } \\
\text { \#Losentimos } \\
\text { \#conprofundo } \\
\text { dolor }\end{array}$ & $\begin{array}{c}\text { medios de } \\
\text { comunicación }\end{array}$ & & $X$ & $\begin{array}{l}\text { El objetivo es que el } \\
\text { HT se posicione } \\
\text { como trending Topic } \\
\text { y la sociedad sepa } \\
\text { del luto y respeto de } \\
\text { la empresa hacia las } \\
\text { víctimas }\end{array}$ \\
\hline $\begin{array}{l}\text { 10:00 a.m. } \\
\text { A 11:00 } \\
\text { a.m. }\end{array}$ & $\begin{array}{l}\text { Reunión del } \\
\text { gerente de } \\
\text { recursos } \\
\text { humanos, un } \\
\text { representante } \\
\text { de los } \\
\text { trabajadores y } \\
\text { el Dircom }\end{array}$ & Colaboradores & $X$ & & $\begin{array}{l}\text { Se busca tener una } \\
\text { reunión sincera dónde } \\
\text { la empresa se } \\
\text { comprometa a } \\
\text { solucionar sus } \\
\text { reclamos y ellos se } \\
\text { vuelvan voceros de las } \\
\text { fortalezas de la } \\
\text { empresa. (Reunión } \\
\text { privada) } \\
\end{array}$ \\
\hline 10:00 a.m. & $\begin{array}{c}\text { Convocatoria a } \\
\text { conferencia de } \\
\text { prensa } \\
\text { (Twitter) }\end{array}$ & $\begin{array}{c}\text { Medios de } \\
\text { comunicación, }\end{array}$ & & $X$ & $\begin{array}{c}\text { La invitación a la } \\
\text { prensa será a través de } \\
\text { la página web y vía } \\
\text { Twitter }\end{array}$ \\
\hline
\end{tabular}




\begin{tabular}{|c|c|c|c|c|c|}
\hline $\begin{array}{c}12: 00 \\
\text { mediodía }\end{array}$ & $\begin{array}{c}\text { Conferencia de } \\
\text { Prensa }\end{array}$ & $\begin{array}{c}\text { Familiares, } \\
\text { medios de } \\
\text { comunicación, } \\
\text { MTC y la } \\
\text { Dirección } \\
\text { General de } \\
\text { Aeronáutica } \\
\text { Civil (DGAC) }\end{array}$ & $X$ & $X$ & $\begin{array}{l}\text { Se tienen } 3 \text { horas } \\
\text { para juntar y } \\
\text { canalizar toda la } \\
\text { información y } 1 \text { hora } \\
\text { para prepararse. En } \\
\text { esta conferencia se } \\
\text { indicará que se le } \\
\text { brindará facilidades } \\
\text { a las autoridades } \\
\text { para las } \\
\text { investigaciones. }\end{array}$ \\
\hline $\begin{array}{l}12: 30 \\
\text { p.m. }\end{array}$ & $\begin{array}{l}\text { Habilitación de } \\
\text { una línea } \\
\text { telefónica para } \\
\text { los familiares } \\
\text { de las víctimas } \\
\text { y otra para } \\
\text { medios de } \\
\text { comunicación }\end{array}$ & $\begin{array}{l}\text { Familiares y } \\
\text { medios de } \\
\text { comunicación }\end{array}$ & $\mathrm{X}$ & X & $\begin{array}{l}\text { En un mundo cada } \\
\text { vez más digital la } \\
\text { comunicación se } \\
\text { realiza por este } \\
\text { medio, sin embargo } \\
\text { escuchar la voz de } \\
\text { otra persona (bien } \\
\text { manejada) puede } \\
\text { disminuir la congoja } \\
\text { de los familiares. }\end{array}$ \\
\hline 13:00 & $\begin{array}{l}\text { Habilitación de } \\
\text { una línea } \\
\text { telefónica para } \\
\text { clientes }\end{array}$ & Clientes & & $X$ & $\begin{array}{l}\text { Informar sobre la } \\
\text { suspensión o } \\
\text { reprogramación de } \\
\text { sus vuelos }\end{array}$ \\
\hline $\begin{array}{l}\text { 14:00 } \\
\text { (Horario } \\
\text { flexible) }\end{array}$ & $\begin{array}{l}\text { Comunicado } \\
\text { (Twitter y } \\
\text { página web) }\end{array}$ & $\begin{array}{l}\text { Familiares y } \\
\text { medios de } \\
\text { comunicación }\end{array}$ & & $X$ & $\begin{array}{c}\text { En momentos de } \\
\text { crisis la información } \\
\text { nueva y relevante a } \\
\text { la sociedad es vital } \\
\text { para evitar } \\
\text { especulaciones }\end{array}$ \\
\hline $\begin{array}{c}\text { 17:00 } \\
\text { (Horario } \\
\text { flexible) }\end{array}$ & $\begin{array}{c}\text { Comunicado } \\
\text { (Twitter y } \\
\text { página web) }\end{array}$ & $\begin{array}{l}\text { Familiares y } \\
\text { medios de } \\
\text { comunicación }\end{array}$ & & $X$ & $\begin{array}{c}\text { En momentos de } \\
\text { crisis la información } \\
\text { nueva y relevante a } \\
\text { la sociedad es vital } \\
\text { para evitar } \\
\text { especulaciones }\end{array}$ \\
\hline $\begin{array}{c}\text { 20:00 } \\
\text { (Horario } \\
\text { flexible) }\end{array}$ & $\begin{array}{c}\text { Comunicado } \\
\text { (Twitter y } \\
\text { página web) }\end{array}$ & $\begin{array}{l}\text { Familiares y } \\
\text { medios de } \\
\text { comunicación }\end{array}$ & & $X$ & $\begin{array}{c}\text { En momentos de } \\
\text { crisis la información } \\
\text { nueva y relevante a } \\
\text { la sociedad es vital } \\
\text { para evitar } \\
\text { especulaciones }\end{array}$ \\
\hline
\end{tabular}




\begin{tabular}{|c|c|c|c|c|c|}
\hline $\begin{array}{c}\text { 12:00 } \\
\text { medianoc } \\
\text { he }\end{array}$ & $\begin{array}{c}\text { Comunicado } \\
\text { (Twitter y } \\
\text { página web) } \\
\text { flexible) }\end{array}$ & $\begin{array}{c}\text { Familiares y } \\
\text { medios de } \\
\text { comunicación }\end{array}$ & & X & $\begin{array}{c}\text { En momentos de } \\
\text { crisis la información } \\
\text { nueva y relevante a } \\
\text { la sociedad es vital } \\
\text { para evitar } \\
\text { especulaciones }\end{array}$ \\
\hline
\end{tabular}

Día martes 11 de junio de 2019

\begin{tabular}{|c|c|c|c|c|c|}
\hline Hora & $\begin{array}{c}\text { Actividad a } \\
\text { realizar }\end{array}$ & $\begin{array}{l}\text { Grupo de } \\
\text { interés }\end{array}$ & Offline & Online & Justificación \\
\hline 3:00 a.m. & $\begin{array}{c}\text { Comunicado } \\
\text { (Twitter y } \\
\text { página web) }\end{array}$ & $\begin{array}{l}\text { Familiares y } \\
\text { medios de } \\
\text { comunicación }\end{array}$ & & $X$ & $\begin{array}{c}\text { En momentos de } \\
\text { crisis la información } \\
\text { nueva y relevante a } \\
\text { la sociedad es vital } \\
\text { para evitar } \\
\text { especulaciones }\end{array}$ \\
\hline 7:00 am & $\begin{array}{l}\text { Difusión de un } \\
\text { vídeo con un } \\
\text { líder y cinco } \\
\text { trabajadores } \\
\text { (Twitter, } \\
\text { Facebook y } \\
\text { página web) }\end{array}$ & $\begin{array}{l}\text { Familiares y } \\
\text { medios de } \\
\text { comunicación }\end{array}$ & $X$ & & $\begin{array}{l}\text { Mostrar empatía y } \\
\text { solidaridad por las } \\
\text { víctimas y sus } \\
\text { familiares de parte } \\
\text { de toda la compañía }\end{array}$ \\
\hline 8:00 a.m. & $\begin{array}{l}\text { Reunión con } \\
\text { los } \\
\text { colaboradores }\end{array}$ & Colaboradores & $X$ & & $\begin{array}{l}\text { Informar sobre la } \\
\text { situación }\end{array}$ \\
\hline 8:00 a.m. & $\begin{array}{l}\text { Comunicado } \\
\text { (Twitter y } \\
\text { página web) }\end{array}$ & $\begin{array}{l}\text { Familiares y } \\
\text { medios de } \\
\text { comunicación }\end{array}$ & & $X$ & $\begin{array}{l}\text { En momentos de } \\
\text { crisis la información } \\
\text { nueva y relevante a } \\
\text { la sociedad es vital } \\
\text { para evitar } \\
\text { especulaciones }\end{array}$ \\
\hline $\begin{array}{l}\text { 11:00 } \\
\text { a.m. }\end{array}$ & $\begin{array}{l}\text { Reunión para } \\
\text { realizar misa el } \\
\text { domingo } 16\end{array}$ & $\begin{array}{c}\text { Acción } \\
\text { pensada en los } \\
\text { familiares de } \\
\text { las víctimas }\end{array}$ & $\mathrm{X}$ & & $\begin{array}{l}\text { En esta reunión se } \\
\text { coordina los } \\
\text { permisos y recursos } \\
\text { a necesitar para la } \\
\text { misa }\end{array}$ \\
\hline $\begin{array}{l}15: 00 \\
\text { p.m. }\end{array}$ & $\begin{array}{l}\text { Comunicado } \\
\text { (Twitter y } \\
\text { página web) }\end{array}$ & $\begin{array}{l}\text { Familiares y } \\
\text { medios de } \\
\text { comunicación }\end{array}$ & & $X$ & $\begin{array}{c}\text { En momentos de } \\
\text { crisis la información } \\
\text { nueva y relevante a } \\
\text { la sociedad es vital } \\
\text { para evitar } \\
\text { especulaciones }\end{array}$ \\
\hline $16: 00$ & $\begin{array}{l}\text { Reunión con } \\
\text { proveedores de }\end{array}$ & Proveedores & $X$ & & $\begin{array}{l}\text { Los proveedores son } \\
\text { aliados estratégicos } \\
\text { y pueden servir de }\end{array}$ \\
\hline
\end{tabular}




\begin{tabular}{|c|c|c|c|c|c|}
\hline p.m. & $\begin{array}{c}\text { productos y } \\
\text { servicios }\end{array}$ & & & $\begin{array}{c}\text { escudo frente a } \\
\text { opiniones negativas } \\
\text { en medios digitales }\end{array}$ \\
\hline $22: 00$ & $\begin{array}{c}\text { Comunicado } \\
\text { (Twitter y } \\
\text { página web) }\end{array}$ & $\begin{array}{c}\text { Familiares y } \\
\text { medios de } \\
\text { comunicación }\end{array}$ & & $\mathrm{X}$ & $\begin{array}{c}\text { En momentos de } \\
\text { crisis la información } \\
\text { nueva y relevante a } \\
\text { la sociedad es vital } \\
\text { para evitar } \\
\text { especulaciones }\end{array}$ \\
\hline
\end{tabular}

Día miércoles 12 de junio al domingo 16 de junio de 2019

\begin{tabular}{|c|c|c|c|c|c|c|}
\hline Fecha & Hora & $\begin{array}{l}\text { Actividad a } \\
\text { realizar }\end{array}$ & $\begin{array}{l}\text { Grupo de } \\
\text { interés }\end{array}$ & Offline & Online & Justificación \\
\hline $\begin{array}{c}\text { Miércoles } \\
12\end{array}$ & 8:00 a.m. & $\begin{array}{l}\text { Reunión con los } \\
\text { colaboradores }\end{array}$ & Colaboradores & $X$ & & $\begin{array}{l}\text { Los } \\
\text { colaboradores } \\
\text { deben estar } \\
\text { informados } \\
\text { para no } \\
\text { generar } \\
\text { zozobra dentro } \\
\text { de la compañía }\end{array}$ \\
\hline $\begin{array}{c}\text { Miércoles } \\
12\end{array}$ & $\begin{array}{c}\text { 8:00 } \\
\text { a.m./3:00 } \\
\text { p.m. y } \\
\text { 23:00 p.m. }\end{array}$ & $\begin{array}{c}03 \text { Comunicados } \\
\text { al día } \\
\text { (Twitter y } \\
\text { página web) }\end{array}$ & $\begin{array}{l}\text { Familiares y } \\
\text { medios de } \\
\text { comunicación }\end{array}$ & & $X$ & $\begin{array}{l}\text { En momentos } \\
\text { de crisis, la } \\
\text { información } \\
\text { nueva y } \\
\text { relevante a la } \\
\text { sociedad es } \\
\text { vital para } \\
\text { evitar } \\
\text { especulaciones }\end{array}$ \\
\hline Jueves 13 & 8:00 a.m. & $\begin{array}{l}\text { Reunión con los } \\
\text { colaboradores }\end{array}$ & Colaboradores & $X$ & & $\begin{array}{l}\text { Los } \\
\text { colaboradores } \\
\text { deben estar } \\
\text { informados } \\
\text { para no } \\
\text { generar } \\
\text { zozobra dentro } \\
\text { de la compañía }\end{array}$ \\
\hline Jueves 13 & $\begin{array}{c}\text { 8:00 } \\
\text { a.m./3:00 } \\
\text { p.m. y } \\
\text { 23:00 p.m. }\end{array}$ & $\begin{array}{c}03 \text { Comunicados } \\
\text { al día } \\
\text { (Twitter y } \\
\text { página web) }\end{array}$ & $\begin{array}{l}\text { Familiares y } \\
\text { medios de } \\
\text { comunicación }\end{array}$ & & $X$ & $\begin{array}{l}\text { En momentos } \\
\text { de crisis la } \\
\text { información } \\
\text { nueva y } \\
\text { relevante a la } \\
\text { sociedad es } \\
\text { vital para } \\
\text { evitar } \\
\text { especulaciones }\end{array}$ \\
\hline & & & & & & $\begin{array}{l}\text { En momentos } \\
\text { de crisis la }\end{array}$ \\
\hline
\end{tabular}




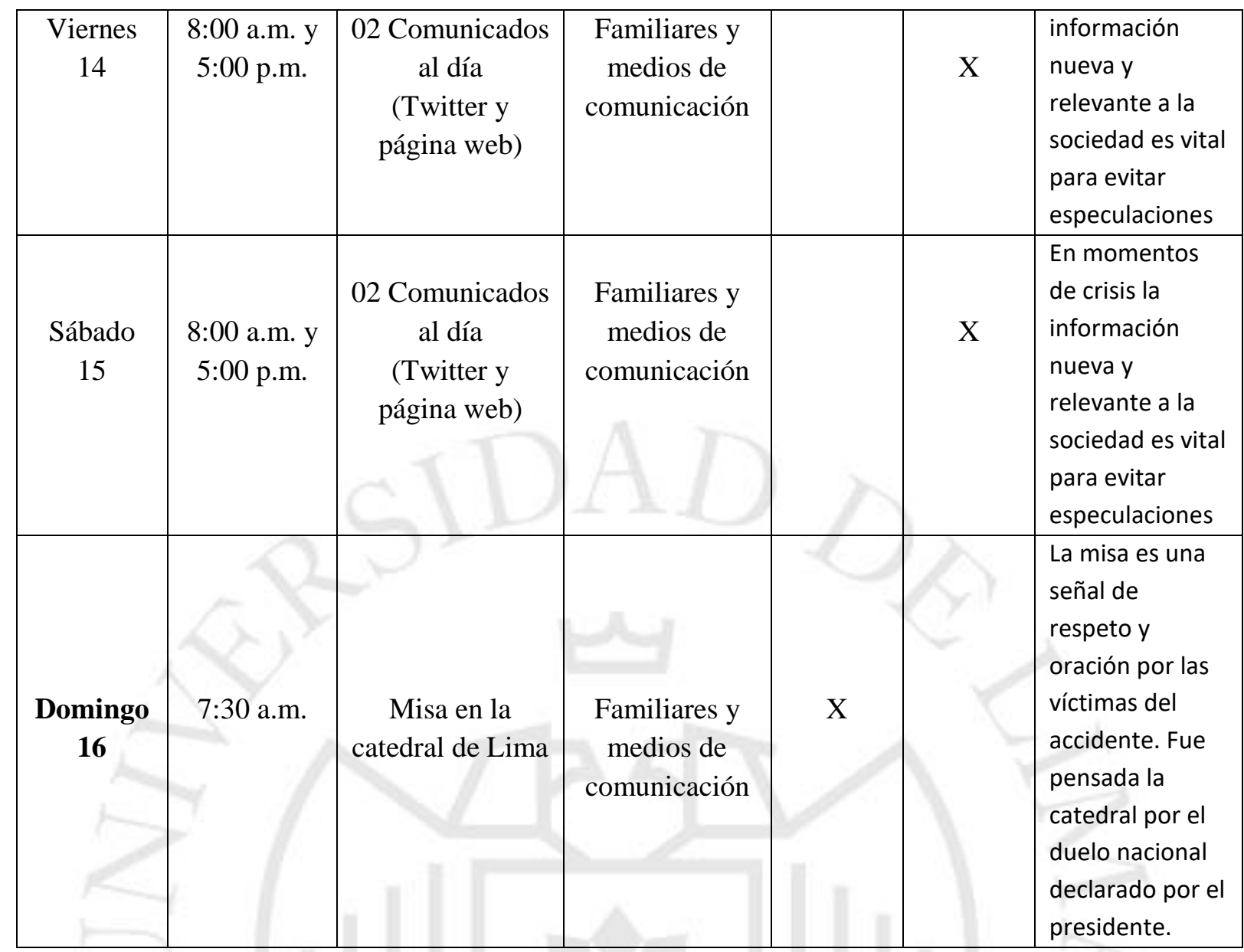

Para tomar una mejor decisión de cuánto tiempo la compañía debe acompañar a los familiares en el proceso de duelo y qué acciones de comunicación realizar. Primero se debe entender el aspecto psicológico de los deudos.

El proceso de duelo ante la muerte de un ser querido es distinto de una cultura a otra o incluso de una persona a otra que pertenecen a una misma cultura.

Las fases de duelo que encontramos son cuatro $^{10}$ :

1) Desconcierto e incredulidad: Es la primera reacción que tienen los familiares ante la noticia. Es la negación de la realidad.

2) Tristeza profunda y agresividad: Se producen reacciones de ira y desconcierto.

3) Desesperación y depresión: Es la etapa anterior a la resignación en la que se produce apatía, tristeza y estado de fragilidad.

4) Aceptación: Es el estado en el que de alguna manera se cierra el dolor, aunque nunca completamente. Además progresivamente se siente la necesidad de continuar con las actividades diarias.

${ }^{10}$ Fuente: Blog PsicoAyuda 
Para los mensajes de duelo en las redes sociales y página web se estima mostrar los lazos negros de duelo de un mes como mínimo y máximo de tres, dependiendo las circunstancias. En cuanto a los comunicados mostrarlos como máximo durante un mes en las redes sociales y página web.

Después de la primera semana se estima mostrar uno diario. Si ameritase el caso.

Las misas del mes y del año son importantes para mostrar el respaldo a los familiares de las víctimas. Sin mencionar el acompañamiento psicológico a los familiares. Sin embargo este aspecto escapa a las decisiones del área de comunicaciones.

Como responsables de Comunicación apoyamos y respaldamos el acompañamiento psicológico de los deudos porque cierra el círculo de dolor de una manera sana.

\section{Después de un mes y un año}

\begin{tabular}{|c|c|c|c|c|c|c|}
\hline Fecha & Hora & $\begin{array}{l}\text { Actividad a } \\
\text { realizar }\end{array}$ & $\begin{array}{c}\text { Grupo de } \\
\text { interés }\end{array}$ & Offline & Online & Justificación \\
\hline $\begin{array}{c}\text { Martes } \\
\text { 09 de } \\
\text { julio } \\
2019\end{array}$ & 8:00 a.m. & Misa & Familiares & X & & $\begin{array}{l}\text { La misa es una } \\
\text { señal de } \\
\text { respeto y } \\
\text { oración por las } \\
\text { víctimas del } \\
\text { accidente. A un } \\
\text { mes del } \\
\text { accidente. }\end{array}$ \\
\hline $\begin{array}{c}\text { Martes } \\
09 \text { de } \\
\text { junio } \\
2020\end{array}$ & 8:00 a.m. & Misa & Familiares & $X$ & & $\begin{array}{l}\text { La misa es una } \\
\text { señal de } \\
\text { respeto y } \\
\text { oración por las } \\
\text { víctimas del } \\
\text { accidente. A un } \\
\text { año del } \\
\text { accidente. }\end{array}$ \\
\hline
\end{tabular}

Cuadro de gastos durante la gestión de la crisis:

\begin{tabular}{|c|c|}
\hline Actividad a realizar & Total \\
\hline $\begin{array}{c}\text { Monitoreo de medios } \\
\text { durante la crisis }\end{array}$ & $\mathrm{S} / 20.000$ \\
\hline Elaboración de video & $\mathrm{S} / 5.000$ \\
\hline Misa 16 junio 2019 & $\mathrm{~S} / 8.000$ \\
\hline & $\mathrm{S} / 33.000$ \\
\hline
\end{tabular}

Todos los gastos de las demás acciones de la gestión de la crisis son parte del presupuesto del área de Comunicaciones. 


\section{Post crisis: Capitalización y prevención de crisis}

\begin{tabular}{|c|c|}
\hline $\begin{array}{c}1 \text { Objetivo de comunicación (¿Qué quiero } \\
\text { alcanzar?) }\end{array}$ & $\begin{array}{c}\text { Controlar los daños en el posicionamiento } \\
\text { reputacional }\end{array}$ \\
\hline $\begin{array}{c}\text { Prioridad Estratégica (vinculado al ámbito } \\
\text { o enfoque de acción a desarrollar las } \\
\text { acciones) }\end{array}$ & Medios Digitales \\
\hline Estrategia (¿Cómo lo voy & $\begin{array}{l}\text { Visibilizar los valores de Viaje Lindo } \\
\text { Airlines (VLA), así como los programas } \\
\text { de Responsabilidad Social Empresarial } \\
\text { que busquen generar valor a la } \\
\text { organización. }\end{array}$ \\
\hline Público ob & $\begin{array}{l}\text { El público objetivo son los clientes, } \\
\text { potenciales clientes y } \\
\text { comunicación para que reboten la } \\
\text { información a la sociedad en general para } \\
\text { conectar con el público y generar } \\
\text { engagement. }\end{array}$ \\
\hline $\begin{array}{l}\text { Acciones (matriz) tácticas (descrip } \\
\text { las acciones) }\end{array}$ & $\begin{array}{l}\text { Acción 1: Realizar el storytelling como } \\
\text { herramienta de presentación de la historia } \\
\text { de la compañía en Facebook. } \\
\text { Acción 2: Elaboración de campañas en } \\
\text { Twitter durante un año comunicando los } \\
\text { valores y programas de RSE } \\
\text { Acción 3: Creación de una página web } \\
\text { que visualice la historia de la empresa, } \\
\text { valores y reconocimientos obtenidos en } \\
\text { Responsabilidad social de manera } \\
\text { interactiva. }\end{array}$ \\
\hline Responsabilidad de trabajo & Área de Marketing \\
\hline Meta & $\begin{array}{l}\text { Lograr que el } 30 \% \text { de los viajeros } \\
\text { nacionales en el aeropuerto Jorge Chávez } \\
\text { conozcan los valores mencionados y sus } \\
\text { programas de RSE en el lapso de } 1 \text { año. }\end{array}$ \\
\hline & $\begin{array}{l}\text { Acción 1: Medición del número de } \\
\text { visitas, alcance, Me gusta, compartidos, } \\
\text { personas. } \\
\text { Herramienta de medición: Facebook } \\
\text { Analitics } \\
\text { Acción 2: Medición de tasa de } \\
\text { interacción, clicks de enlace, me gusta } \\
\text { retweets, respuestas, número de } \\
\text { reproducciones de videos, tasa de }\end{array}$ \\
\hline
\end{tabular}




\begin{tabular}{|c|l|}
\hline Indicadores y herramientas & finalización, minutos visualizados y \\
& retención de la audiencia, impresiones, \\
& seguidores, menciones, visitas al perfil. \\
& Herramienta de medición: Twitter \\
& Analitics \\
& Acción 3: Número de visitas, alcances e \\
& impresiones, tráfico web, sistema \\
& operativo, proveedor de servicios y \\
& resolución de pantalla. \\
& Herramienta de medición: Google \\
& Analitics \\
\hline Presupuesto & Acción 1: Servicios de una agencia \\
& digital: S/ 8.000 \\
& Acción 2: Servicios de una agencia \\
& digital: \\
& S/ 9.000 \\
& Acción 3: Elaboración, diseño, hosting y \\
& mantenimiento de la página web: S/12. \\
& 000 \\
\hline
\end{tabular}

\begin{tabular}{|c|c|}
\hline $\begin{array}{c}2 \text { Objetivo de comunicación (¿Qué quiero } \\
\text { alcanzar?) }\end{array}$ & $\begin{array}{c}\text { Generar una mejor relación entre empresa } \\
\text { y colaboradores }\end{array}$ \\
\hline $\begin{array}{c}\text { Prioridad Estratégica (vinculado al ámbito } \\
\text { o enfoque de acción a desarrollar las } \\
\text { acciones) }\end{array}$ & \multicolumn{1}{c|}{ Comunicación interna } \\
\hline Estrategia (¿Cómo lo voy a alcanzar?) & $\begin{array}{l}\text { Mejorar las relaciones entre empresa } \\
\text { empleadora y colaboradores, entendiendo } \\
\text { sus necesidades laborales y de } \\
\text { reconocimiento. }\end{array}$ \\
\hline Público objetivo (grupo de interés) & $\begin{array}{l}\text { Los colaboradores de Viaje Lindo } \\
\text { Airlines }\end{array}$ \\
\hline Acciones (matriz) tácticas (descripción de & $\begin{array}{l}\text { Acción 1: Elaborar dos encuestas de } \\
\text { clima laboral a todos los colaboradores. } \\
\text { Acción 2: Campaña de reconocimiento } \\
\text { "En viaje Lindo las personas son } \\
\text { primero, tú nos importas" }\end{array}$ \\
\hline Responsabilidad de trabajo & $\begin{array}{l}\text { Acción 3: Efectuar activaciones dentro de } \\
\text { la empresa donde se potencien los valores } \\
\text { de la seguridad, puntualidad y cuidado del } \\
\text { medio ambiente. }\end{array}$ \\
\hline & Área de Comunicación Interna \\
\hline & Mejorar el clima laboral donde los \\
\hline
\end{tabular}




\begin{tabular}{|c|l|}
\hline Meta & $\begin{array}{l}\text { indicadores: Sentido de pertenencia, } \\
\text { liderazgo y reconocimientos llegan a más } \\
\text { del 80\% de los colaboradores }\end{array}$ \\
\hline Indicadores y herramientas & $\begin{array}{l}\text { Acción 1: La herramienta a utilizar es la } \\
\text { encuesta de clima laboral } \\
\text { Acción 2: Mediante encuestas y } \\
\text { entrevistas a profundidad } \\
\text { Acción 3: Medición de la recordación de } \\
\text { los valores y programas de RSE de la } \\
\text { empresa. } \\
\text { Herramienta de medición: encuestas }\end{array}$ \\
\hline Presupuesto & $\begin{array}{l}\text { Acción 1: Servicios de una empresa que } \\
\text { realiza encuestas de clima: } 40 \text { 000 (enero } \\
\text { y noviembre) } \\
\text { Acción 2: } 24000 \text { por los } 6 \text { meses } \\
\text { Acción 3: } 35000 \text { (5 veces al año) }\end{array}$ \\
\hline
\end{tabular}

\begin{tabular}{|c|c|}
\hline $\begin{array}{c}3 \text { Objetivo de comunicación (¿Qué quiero } \\
\text { alcanzar?) }\end{array}$ & $\begin{array}{l}\text { Desarrollar un plan de prevención de una } \\
\text { crisis }\end{array}$ \\
\hline \multicolumn{2}{|l|}{ Prioridad Estratégica (vinculado al ámbito } \\
\hline $\begin{array}{c}\text { o enfoque de acción a desarrollar las } \\
\text { acciones) }\end{array}$ & Plan de crisis \\
\hline Estrategia (¿Cómo lo voy a alcanzar?) & \multirow{2}{*}{$\begin{array}{l}\text { Mediante el análisis, práctica y } \\
\text { compromiso de los líderes de la compañía }\end{array}$} \\
\hline & \\
\hline Público objetivo (grupo de interés) & \multirow{2}{*}{$\begin{array}{l}\text { Los líderes de la empresa y los altos } \\
\text { directivos de la compañía }\end{array}$} \\
\hline \multirow[b]{2}{*}{$\begin{array}{l}\text { Acciones (matriz) tácticas (descripción de } \\
\text { las acciones) }\end{array}$} & \\
\hline & $\begin{array}{l}\text { Acción 1: Elaboración del Plan de crisis } \\
\text { Acción 2: Talleres de Media training para } \\
\text { todos los altos directivos de la compañía. } \\
\text { Acción 3: Reunión periódica para } \\
\text { practicar el Plan de Crisis }\end{array}$ \\
\hline Responsabilidad de trabajo & Área de Prensa \\
\hline Meta & $\begin{array}{l}\text { Que los líderes y altos directivos de la } \\
\text { compañía se comprometan, practiquen el } \\
\text { Plan de crisis y tengan las pautas } \\
\text { generales de cómo actuar ante tal } \\
\text { situación }\end{array}$ \\
\hline Indicadores y herramientas & $\begin{array}{l}\text { Acción 1: Asistencias e inasistencias de } \\
\text { los líderes a las reuniones con la empresa } \\
\text { tercerizada para elaborar el Plan de crisis. } \\
\text { Acción 2: Con notas de puntuación } \\
\text { vigesimal de parte de los que imparten el } \\
\text { taller. }\end{array}$ \\
\hline
\end{tabular}




\begin{tabular}{|l|l|}
\hline & $\begin{array}{l}\text { Acción 3: Porcentaje de asistencias e } \\
\text { inasistencias. }\end{array}$ \\
\hline \multirow{3}{*}{ Presupuesto } & $\begin{array}{l}\text { Acción 1: El precio aproximado para el } \\
\text { Plan de crisis: } 16000 \\
\text { Acción 2: Los talleres para un grupo de } \\
12 \text { personas: } 14000 \text { por 3 veces } 42000 \\
\text { Acción 3: Costo de tiempo }\end{array}$ \\
\hline
\end{tabular}

\begin{tabular}{|c|c|}
\hline $\begin{array}{c}4 \text { Objetivo de comunicación (¿Qué quiero } \\
\text { alcanzar?) }\end{array}$ & Generar una cultura corporativa \\
\hline $\begin{array}{c}\text { Prioridad Estratégica (vinculado al ámbi } \\
\text { o enfoque de acción a desarrollar las } \\
\text { acciones) }\end{array}$ & Cultura corporativa \\
\hline Estrategia (¿Cómo lo voy a alcanzar & $\begin{array}{l}\text { Mediante mensajes, juegos, rituales, } \\
\text { símbolos aportar cohesión y compromiso } \\
\text { en los colaboradores de la compañía }\end{array}$ \\
\hline Público objeti & $\begin{array}{l}\text { Los colaboradores de los mandos medios } \\
\text { hacia abajo. }\end{array}$ \\
\hline $\begin{array}{c}\text { Acciones (matriz) tácticas (descripción de } \\
\text { las acciones) }\end{array}$ & $\begin{array}{l}\text { Acción 1: Unificación de los grupos de } \\
\text { WhatsApp, Facebook (grupo cerrado, sólo } \\
\text { colaboradores) y los gestione el área de } \\
\text { Comunicación y se comunique los } \\
\text { símbolos de la empresa, normas } \\
\text { importantes, historia, valores, ritos, } \\
\text { ceremonias y los héroes de la empresa. } \\
\text { Acción 2: Realizar mini campaña de } \\
\text { juegos por el Facebook interno, ligados a } \\
\text { los valores de la empresa y los programas } \\
\text { en RSE (Los ganadores recibirán \% de } \\
\text { descuentos en viajes, adicionales a los que } \\
\text { ya tienen) } \\
\text { Acción 3: Diseño de concursos solamente } \\
\text { por Intranet, dónde se responda } 3 \\
\text { preguntas sobre la historia y el origen de } \\
\text { la compañía. (Los ganadores podrán salir } \\
45 \text { minutos antes). } \\
\text { Acción 4: Activación por cada área de la } \\
\text { empresa donde se comunique mediante } \\
\text { juegos los símbolos de la empresa, } \\
\text { normas importantes, historia, valores, } \\
\text { ritos, ceremonias y los héroes de la } \\
\text { empresa, entre otros. }\end{array}$ \\
\hline
\end{tabular}




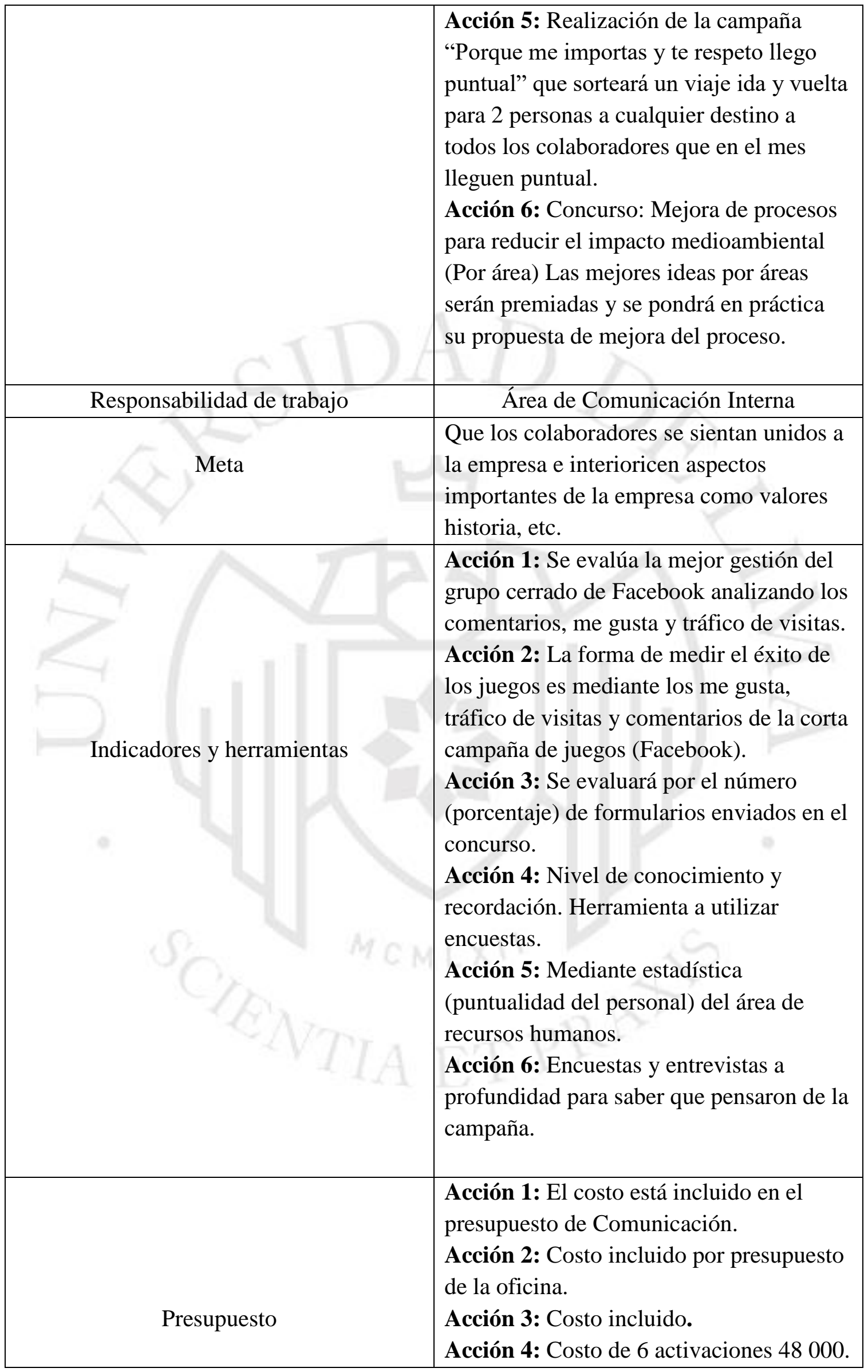




\begin{tabular}{|l|l|}
\hline & Acción 5: La estadística es interna de la \\
& empresa (VLA). RR.HH. \\
& Acción 6: Cantidad presupuestada 80000 \\
premios.
\end{tabular}

\begin{tabular}{|c|c|}
\hline $\begin{array}{l}5 \text { Objetivo de comunicación (¿Qué quiero } \\
\text { alcanzar?) }\end{array}$ & $\begin{array}{l}\text { Creación de herramientas digitales para } \\
\text { prevenir el crecimiento de una crisis }\end{array}$ \\
\hline $\begin{array}{c}\text { Prioridad Estratégica (vinculado al ámbito } \\
\text { o enfoque de acción a desarrollar las } \\
\text { acciones) }\end{array}$ & Medios Digitales \\
\hline Estrategia $(¿ \mathrm{C}$ & $\begin{array}{l}\text { Mediante mensajes de solidaridad y } \\
\text { empatía con los familiares de las víctimas } \\
\text { en medios digitales. Así como } \\
\text { información importante actualizada, } \\
\text { instrucciones para los afectados, } \\
\text { comunicados, entre otros. }\end{array}$ \\
\hline Público objetivo (grupo de interés) & Familiares de las víctimas \\
\hline $\begin{array}{c}\text { Acciones (matriz) tácticas (descrip } \\
\text { las acciones) }\end{array}$ & $\begin{array}{l}\text { Acción 1: La disposición de una página } \\
\text { oculta (dark site) que esté lista para } \\
\text { cuando suceda algún accidente y contenga } \\
\text { información relevante. } \\
\text { Acción 2: La creación de un blog de } \\
\text { mensaje de condolencias. }\end{array}$ \\
\hline Responsabilidad de trabajo & Área de Comunicación Externa y RR.PP \\
\hline Meta & $\begin{array}{l}\text { Que el número de visitas a la página web } \\
\text { oficial sea la misma al dark site y al blog. }\end{array}$ \\
\hline Indicadores y herramientas & $\begin{array}{l}\text { Acción 1: Número de visitas de la página } \\
\text { y tráfico web. Herramienta de medición: } \\
\text { Google Analitics. } \\
\text { Acción 2: Porcentaje de mensajes de } \\
\text { condolencias escritos por cada usuario } \\
\text { que ingreso al blog. Herramienta de } \\
\text { medición: Google Analitics. }\end{array}$ \\
\hline Presupuesto & $\begin{array}{l}\text { Acción 1: Elaboración, diseño, hosting y } \\
\text { mantenimiento de la página web } \\
\text { S/10.000. } \\
\text { Acción 2: Elaboración y diseño S/2.000. }\end{array}$ \\
\hline
\end{tabular}




\section{Cuadro de gastos en la post crisis: Capitalización y prevención de crisis}

\begin{tabular}{|c|c|c|c|}
\hline 1 Objetivo & Acción & Indicador & TOTAL \\
\hline \multirow{3}{*}{$\begin{array}{l}\text { Controlar los } \\
\text { daños en el } \\
\text { posicionamiento } \\
\text { reputacional }\end{array}$} & $\begin{array}{l}\text { Realizar el storytelling } \\
\text { como herramienta de } \\
\text { presentación de la } \\
\text { historia de la compañía } \\
\text { en Facebook. }\end{array}$ & $\begin{array}{l}\text { Medición del número de } \\
\text { visitas, alcance, Me } \\
\text { gusta, compartidos, } \\
\text { personas. } \\
\text { Herramienta de } \\
\text { medición: Facebook } \\
\text { Analitics. }\end{array}$ & $\begin{array}{l}\text { Servicios de una } \\
\text { agencia digital: } \mathrm{S} / \\
8.000\end{array}$ \\
\hline & $\begin{array}{c}\text { Elaboración de } \\
\text { campañas en Twitter } \\
\text { durante un año } \\
\text { comunicando los } \\
\text { valores y programas de } \\
\text { RSE. }\end{array}$ & $\begin{array}{l}\text { Medición de tasa de } \\
\text { interacción, clicks de } \\
\text { enlace, me gusta } \\
\text { retweets, respuestas, } \\
\text { número de } \\
\text { reproducciones de } \\
\text { videos, tasa de } \\
\text { finalización, minutos } \\
\text { visualizados y retención } \\
\text { de la audiencia, } \\
\text { impresiones, seguidores, } \\
\text { menciones, visitas al } \\
\text { perfil. } \\
\text { Herramienta de } \\
\text { medición: Twitter } \\
\text { Analitics. }\end{array}$ & $\begin{array}{c}\text { Servicios de una } \\
\text { agencia digital: } \mathrm{S} / \\
9.000\end{array}$ \\
\hline & $\begin{array}{l}\text { Creación de una página } \\
\text { web que visualice la } \\
\text { historia de la empresa, } \\
\text { valores y } \\
\text { reconocimientos } \\
\text { obtenidos en } \\
\text { Responsabilidad social } \\
\text { de manera interactiva. }\end{array}$ & $\begin{array}{c}\text { Número de visitas, } \\
\text { alcances e impresiones, } \\
\text { tráfico web, sistema } \\
\text { operativo, proveedor de } \\
\text { servicios y resolución de } \\
\text { pantalla. } \\
\text { Herramienta de } \\
\text { medición: Google } \\
\text { Analitics }\end{array}$ & $\begin{array}{l}\text { Elaboración, diseño, } \\
\text { hosting y } \\
\text { mantenimiento de la } \\
\text { página web: S/ } \\
12.000\end{array}$ \\
\hline 2 Objetivo & Acción & Indicador & Sub-total S/ 29.000 \\
\hline \multirow{3}{*}{$\begin{array}{l}\text { Generar una } \\
\text { mejor relación } \\
\text { entre empresa y } \\
\text { colaboradores }\end{array}$} & $\begin{array}{l}\text { Elaborar dos encuestas } \\
\text { de clima laboral a todos } \\
\text { los colaboradores. }\end{array}$ & $\begin{array}{c}\text { La herramienta a utilizar } \\
\text { es la encuesta de clima } \\
\text { laboral }\end{array}$ & $\begin{array}{c}\text { Servicios de una } \\
\text { empresa que realiza } \\
\text { encuestas de clima: } \\
\text { S/ } 40.000 \text { (enero y } \\
\text { noviembre). }\end{array}$ \\
\hline & $\begin{array}{c}\text { Campaña de } \\
\text { reconocimiento } \\
\text { "En viaje Lindo las } \\
\text { personas son primero, } \\
\text { tú nos importas" }\end{array}$ & $\begin{array}{c}\text { Mediante encuestas y } \\
\text { entrevistas a } \\
\text { profundidad }\end{array}$ & $\begin{array}{c}\mathrm{S} / 24.000 \text { por los } 6 \\
\text { meses. }\end{array}$ \\
\hline & Efectuar activaciones & Medición de la & \\
\hline
\end{tabular}




\begin{tabular}{|c|c|c|c|}
\hline & $\begin{array}{l}\text { dentro de la empresa } \\
\text { donde se potencien los } \\
\text { valores de la seguridad, } \\
\text { puntualidad y cuidado } \\
\text { del medio ambiente. }\end{array}$ & $\begin{array}{l}\text { recordación de los } \\
\text { valores y programas de } \\
\text { RSE de la empresa. } \\
\text { Herramienta de } \\
\text { medición: encuestas }\end{array}$ & $\begin{array}{c}\mathrm{S} / 35.000 \text { (5 veces al } \\
\text { año). }\end{array}$ \\
\hline 3 Objetivo & Acción & Indicador & Sub-total S/ 99.000 \\
\hline \multirow{3}{*}{$\begin{array}{l}\text { Desarrollar un } \\
\text { plan de } \\
\text { prevención de } \\
\text { una crisis }\end{array}$} & $\begin{array}{c}\text { Elaboración del Plan de } \\
\text { crisis }\end{array}$ & $\begin{array}{c}\text { Asistencias e } \\
\text { inasistencias de los } \\
\text { líderes a las reuniones } \\
\text { con la empresa } \\
\text { tercerizada para elaborar } \\
\text { el Plan de crisis. }\end{array}$ & $\begin{array}{c}\text { El precio aproximado } \\
\text { para el Plan de crisis: } \\
\text { S/16.000 }\end{array}$ \\
\hline & $\begin{array}{l}\text { Talleres de Media } \\
\text { training para todos los } \\
\text { altos directivos de la } \\
\text { compañía }\end{array}$ & $\begin{array}{c}\text { Con notas de puntuación } \\
\text { vigesimal de parte de los } \\
\text { que imparten el taller. }\end{array}$ & $\begin{array}{l}\text { Los talleres para un } \\
\text { grupo de } 12 \\
\text { personas: } \mathrm{S} / 14.000 \\
\text { por } 3 \text { veces: } \mathrm{S} / \\
42.000\end{array}$ \\
\hline & $\begin{array}{c}\text { Reunión periódica para } \\
\text { practicar el Plan de } \\
\text { Crisis }\end{array}$ & $\begin{array}{l}\text { Porcentaje de asistencias } \\
\text { e inasistencias. }\end{array}$ & Costo de tiempo. \\
\hline 4 Objetivo & Acción & Indicador & Sub-total S/ 58.000 \\
\hline \multirow[t]{3}{*}{$\begin{array}{l}\text { Generar una } \\
\text { cultura } \\
\text { corporativa }\end{array}$} & $\begin{array}{l}\text { Unificación de los } \\
\text { grupos de WhatsApp, } \\
\text { Facebook (grupo } \\
\text { cerrado, sólo } \\
\text { colaboradores) y los } \\
\text { gestione el área de } \\
\text { Comunicación y se } \\
\text { comunique los } \\
\text { símbolos de la } \\
\text { empresa, normas } \\
\text { importantes, historia, } \\
\text { valores, ritos, } \\
\text { ceremonias y los héroes } \\
\text { de la empresa. }\end{array}$ & $\begin{array}{l}\text { Se evalúa la mejor } \\
\text { gestión del grupo } \\
\text { cerrado de Facebook } \\
\text { analizando los } \\
\text { comentarios, me gusta y } \\
\text { tráfico de visitas. }\end{array}$ & $\begin{array}{c}\text { El costo está incluido } \\
\text { en el presupuesto de } \\
\text { Comunicación }\end{array}$ \\
\hline & $\begin{array}{l}\text { Realizar mini campaña } \\
\text { de juegos por el } \\
\text { Facebook interno, } \\
\text { ligados a los valores de } \\
\text { la empresa y los } \\
\text { programas en RSE (Los } \\
\text { ganadores recibirán \% } \\
\text { de descuentos en } \\
\text { viajes, adicionales a los } \\
\text { que ya tienen). }\end{array}$ & $\begin{array}{l}\text { La forma de medir el } \\
\text { éxito de los juegos es } \\
\text { mediante los me gusta, } \\
\text { tráfico de visitas y } \\
\text { comentarios de la corta } \\
\text { campaña de juegos } \\
\text { (Facebook). }\end{array}$ & $\begin{array}{l}\text { Costo incluido por } \\
\text { presupuesto de la } \\
\text { oficina. }\end{array}$ \\
\hline & $\begin{array}{l}\text { Diseño de concursos } \\
\text { solamente por Intranet, }\end{array}$ & & \\
\hline
\end{tabular}




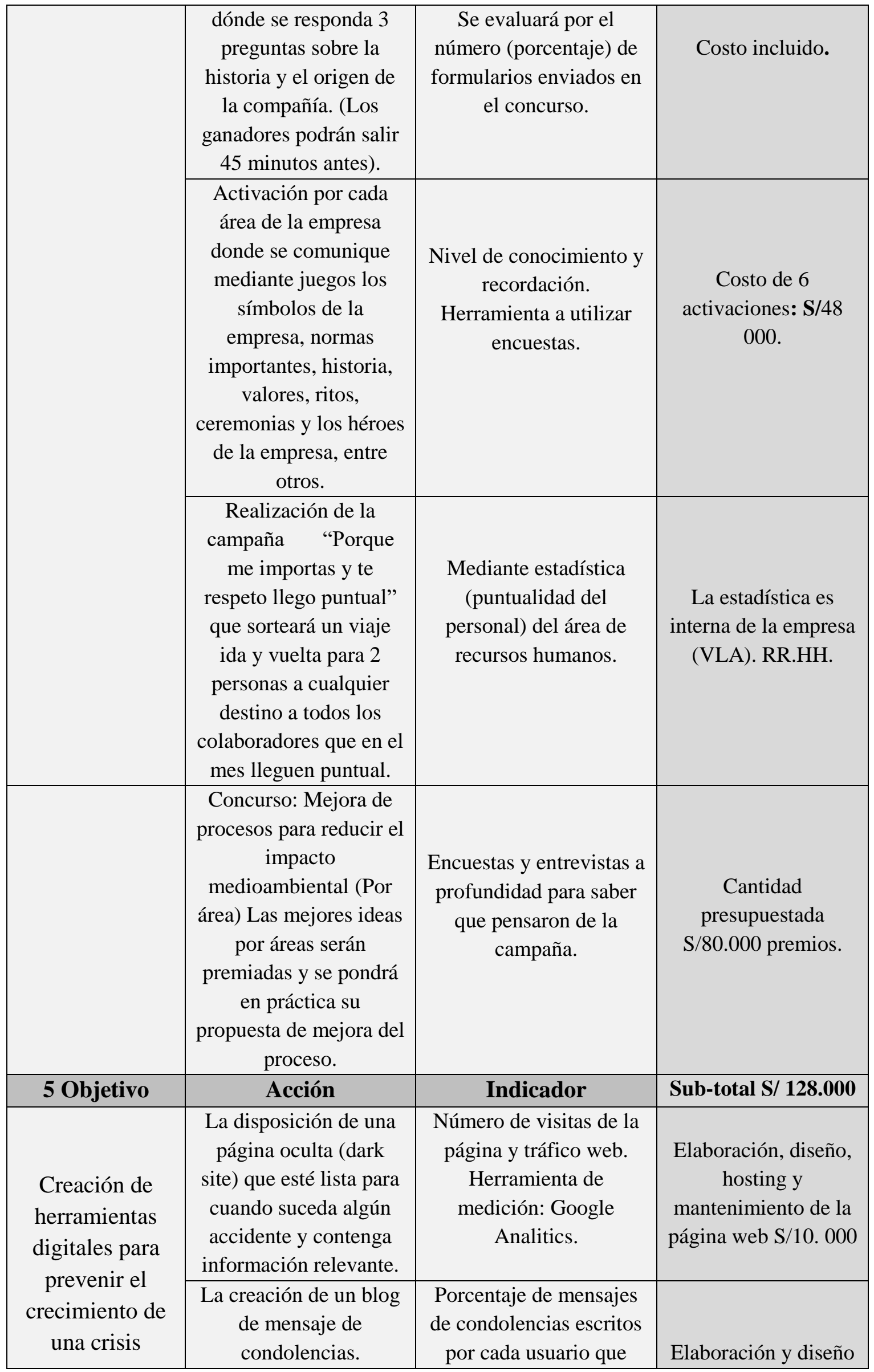




\begin{tabular}{|c|c|c|c|}
\hline & & $\begin{array}{c}\text { ingreso al blog. } \\
\text { Herramienta de } \\
\text { medición: Google } \\
\text { Analitics. }\end{array}$ & S/2.000 \\
\hline TOTAL & & & S/ 314.000 \\
\hline
\end{tabular}

Cuadro de inversión global realizada durante la gestión de la crisis y post crisis:

\begin{tabular}{|c|c|c|c|c|}
\hline $\begin{array}{c}\text { Inversión } \\
\text { realizada } \\
\text { durante la } \\
\text { Gestión de la } \\
\text { Crisis }\end{array}$ & $\begin{array}{c}\text { Inversión } \\
\text { realizada } \\
\text { Post Crisis }\end{array}$ & $\begin{array}{c}\text { Misa (Mes) } \\
\mathbf{9} \text { de julio } \\
\mathbf{2 0 1 9}\end{array}$ & $\begin{array}{c}\text { Misa (Año) } \\
\text { 9 de junio } \\
\mathbf{2 0 2 0}\end{array}$ & Total \\
\hline S/33.000 & & & & $\mathrm{S} / 33.000$ \\
\hline & $\mathrm{S} / 314.000$ & & $\mathrm{~S} / 7.000$ & $\mathrm{~S} / 314.000$ \\
\hline & & $\mathrm{S} / 7.000$ & & $\mathrm{~S} / 14.000$ \\
& & & & $\mathbf{S 1 0 8 . 7 3 4}$ \\
\hline
\end{tabular}

\section{Retorno de la Inversión o ROI (Return On Investment)}

El presente Plan en la post crisis toma énfasis en la comunicación interna y en la relación de nuestro público interno (colaboradores) con el empleador y cómo nuestras acciones de comunicación interna pueden disminuir las tasas de ausentismo, rotación, mayor productividad y lealtad.

El Índice de Rotación de Personal se expresa en términos porcentuales mediante la siguiente fórmula ${ }^{11}$ :

$$
\operatorname{IRP}=\frac{\frac{A+D}{2} \times 100}{\frac{F 1+F 2}{2}}
$$

${ }^{11}$ Fuente: gestiopolis 
Donde:

- A: Número de personas contratadas durante el período considerado.

- D: Personas desvinculadas durante el mismo período.

- F1: Número de trabajadores al comienzo del período considerado

- F2: Número de trabajadores al final del período.

En el mercado peruano Latam tiene aproximadamente 3,576 colaboradores (Referencial) y con una rotación aproximada del $15 \%$ que viene a ser 536 colaboradores (Referencial). Además cuenta con 18 aviones para destinos domésticos (interior del territorio nacional) ${ }^{12}$.

La referencia de la aerolínea antes mencionada, brinda un mejor panorama para realizar la comparación con VLA que tiene 15 aviones Boeing 737-200, 10 aviones BAE 146-300 y la adquisición de 15 Boeing 737-300. Es decir, VLA tendría que tener aproximadamente la misma cantidad de colaboradores que la aerolínea antes mencionada como mínimo para cubrir sus operaciones a nivel nacional.

El costo de cubrir a un nuevo colaborador es la siguiente ${ }^{13}$ :

- Empleado nuevo: 30-50\% del salario anual del empleado.

- De servicio o producción: 40-70\% del salario anual del empleado.

- Administrativo: 50-80\% del salario anual del empleado.

- Hábil en sus labores: 75-100\% del salario anual del empleado.

- Profesional: 75-125\% del salario anual del empleado.

- Especialista altamente hábil: 100 - 150\% del salario anual del empleado.

- Supervisor: $\mathbf{1 0 0 - 1 5 0 \%}$ del salario anual del empleado.

Si la rotación de la aerolínea antes mencionada es aproximadamente del 15\%. La rotación de VLA con malestar laboral debe ser mucho mayor. Lo dejaremos en $15 \%$ para fines prácticos. El porcentaje del costo de reponer a un colaborador varía de acuerdo a la posición, por lo que lo dejaremos en $50 \%$.

El 15\% de 3,576 colaboradores es 536. Es decir, si cada colaborador ganaría S/2.000 el costo de reponer a cada uno sería de $\mathrm{S} / 1.000$ por lo que, esta cantidad por 536 es de $S / 536.000$

\footnotetext{
${ }^{12}$ Fuente: Reporte de Sostenibilidad 2017 - Latam https://www.latam.com/content/dam/LATAM/LAN/Footer/Sostenibilidad/Reportes\%20de\%20Sostenibili dad/Reporte_Sostenibilidad_2017_ES.pdf

${ }^{13}$ Fuente: GNA Partners
} 
En otras palabras. Si a los $\mathrm{S} / 536.000$ restamos el gasto solamente de la post crisis (año 2020) que es S/314.000 monto que después de la resta sale S/222.000 estamos generando ahorro a la compañía.

Es decir, solamente en manejar mejor la Comunicación Interna se tiene un ahorro para la empresa de S/222.000 sin contar que en los objetivos de post crisis también hay acciones que fortalecen la reputación y mejoran el valor intangible de la empresa.

\section{Cronograma 2020}

\section{Enero}

- Campañas en Twitter comunicando los valores y programas de RSE.

- Realización del storytelling.

- Creación de una página web interactiva.

- Elaboración de la encuesta de clima laboral a todos los colaboradores.

- Elaboración del Plan de crisis.

- Unificación de los grupos de WhatsApp, Facebook.

- Creación de un dark site y un blog.

\section{Febrero}

- Campañas en Twitter comunicando los valores y programas de RSE.

- Campaña de reconocimiento "En viaje Lindo las personas son primero, tú nos importas".

- Activaciones dentro de la empresa donde se potencien los valores de seguridad, puntualidad y cuidado del medio ambiente.

- Taller de Media training.

- Diseño de concursos solamente por Intranet.

Marzo

- Campañas en Twitter comunicando los valores y programas de RSE.

- Activaciones dentro de la empresa donde se potencien los valores de seguridad, puntualidad y cuidado del medio ambiente.

- Reunión periódica para practicar el Plan de Crisis.

- Diseño de concursos solamente por Intranet.

\section{Abril}

- Campañas en Twitter comunicando los valores y programas de RSE.

- Realización del storytelling.

- Mini campaña de juegos por el Facebook interno, ligados a los valores de la empresa y los programas en RSE.

- Activación por cada área de la empresa donde se comunique mediante juegos los símbolos de la empresa, normas importantes, historia, valores, ritos, ceremonias y los héroes de la empresa.

Mayo

- Campañas en Twitter comunicando los valores y programas de RSE.

- Reunión periódica para practicar el Plan de Crisis. 
- Activación por cada área de la empresa donde se comunique mediante juegos los símbolos de la empresa, normas importantes, historia, valores, ritos, ceremonias y los héroes de la empresa.

\section{Junio}

- Campañas en Twitter comunicando los valores y programas de RSE.

- Activaciones dentro de la empresa donde se potencien los valores de seguridad, puntualidad y cuidado del medio ambiente.

- Mini campaña de juegos por el Facebook interno, ligados a los valores de la empresa y los programas en RSE.

\section{Julio}

- Campañas en Twitter comunicando los valores y programas de RSE.

- Reunión periódica para practicar el Plan de Crisis.

- Inicio del Concurso: Mejora de procesos para reducir el impacto medioambiental (Por área). Las mejores ideas por áreas serán premiadas y se pondrá en práctica su propuesta de mejora del proceso (Equipos de 5 como máximo).

- Realización de la campaña "Porque me importas y te respeto llego puntual".

\section{Agosto}

- Campañas en Twitter comunicando los valores y programas de RSE.

- Realización del storytelling.

- Taller de Media training.

- Activación por cada área de la empresa donde se comunique mediante juegos los símbolos de la empresa, normas importantes, historia, valores, ritos, ceremonias y los héroes de la empresa.

\section{Septiembre}

- Campañas en Twitter comunicando los valores y programas de RSE.

- Activaciones dentro de la empresa donde se potencien los valores de seguridad, puntualidad y cuidado del medio ambiente.

- Concurso de reducción de los recursos a utilizar que dañen el medio ambiente.

- Activación por cada área de la empresa donde se comunique mediante juegos los símbolos de la empresa, normas importantes, historia, valores, ritos, ceremonias y los héroes de la empresa.

\section{Octubre}

- Campañas en Twitter comunicando los valores y programas de RSE.

- Reunión periódica para practicar el Plan de Crisis.

- Diseño de concursos solamente por Intranet.

- Activación por cada área de la empresa donde se comunique mediante juegos los símbolos de la empresa, normas importantes, historia, valores, ritos, ceremonias y los héroes de la empresa.

\section{Noviembre}

- Campañas en Twitter comunicando los valores y programas de RSE.

- Activaciones dentro de la empresa donde se potencien los valores de seguridad, puntualidad y cuidado del medio ambiente.

- Taller de Media training. 


\section{Diciembre}

- Campañas en Twitter comunicando los valores y programas de RSE.

- Realización del storytelling.

- Diseño de concursos solamente por Intranet.

- Activación por cada área de la empresa donde se comunique mediante juegos los símbolos de la empresa, normas importantes, historia, valores, ritos, ceremonias y los héroes de la empresa.

- Premiación del Concurso: Mejora de procesos para reducir el impacto medioambiental. 


\section{SUSTENTACIÓN}

\subsection{Argumentos conceptuales:}

Las crisis son situaciones que ponen en evidencia el grado de preparación de una organización para hacerle frente. En esos momentos en que el nerviosismo ronda por todas las áreas de la empresa es donde más debe de exigir la serenidad de los líderes.

Lo que nos dicen los entendidos al respecto es que un Plan de crisis es de vital importancia, es como el $\mathrm{ABC}$ de lo que se debe hacer, es una hoja de ruta ya pauteada y que te facilita el fácil desenvolvimiento ante la crisis. A pesar que puede ingresar un nuevo tipo de crisis a la casuística dependiendo del sector. Si la empresa tiene un Plan de crisis y sabe cómo aplicarla es muy probable que salga menos preocupado y librado de la crisis.

Dentro de ese Plan de crisis se encuentra el Comité de crisis en la que los integrantes tienen definidos sus funciones, datos personales y de contacto. Este comité es vital porque centraliza el poder y la capacidad de decisión. Para ser exacto, la máxima decisión recae en el jefe del comité.

Los mensajes a comunicar deben ser pocos y tenerlos presentes en las conferencias de prensa, buscar posicionar esos mensajes.

El vocero de la empresa en todo momento debe mostrar honestidad y hablar con la verdad. Si la prensa se entera que se oculta información juega el efecto bumerán y su reputación se puede ver seriamente afectada. Lo que dicen los entendidos y el sentido común es que las disculpas sinceras con acciones de por medio que avalen esas palabras pueden disminuir la sensación de rabia, frustración de los familiares de las víctimas. Tener en cuenta siempre el respeto por las víctimas y sus familiares.

En este aspecto los talleres de media training son vitales. La gestualidad refuerza o en muchos casos comunica más que las palabras. No se trata de actuar o aparentar, sino ser lo más sinceros posibles y que la sociedad lo entienda de esa manera.

El principal soporte académico del tema de crisis fue la lectura del libro de Paul Remy sobre Manejo de Crisis.

En la segunda parte del trabajo post crisis se busca capitalizar y prevenir futuras crisis para lo cual se tuvo presente desde el inicio el siguiente mensaje "La Reputación nace desde dentro". No es posible concebir realizar una estrategia de reputación, sin primero empezar en casa. Es decir, en nuestros colaboradores (stakeholder clave). Los colaboradores humanizan la marca y son los que representan a la empresa ante los clientes. Si logramos generar engagement, tendremos su compromiso y lealtad, y en tiempo de crisis se convierten en los principales voceros que sirven de escudo (sin pedirlo) ante los ataques. 
La importancia de los Reportes de Sostenibilidad es un punto a favor en las empresas, pues manda un mensaje de transparencia a la sociedad, y cada vez más gente toma en cuenta esto y otras variables para elegir la compra del producto o servicio.

La responsabilidad social empresarial, se entiende como las acciones que están más allá de lo legalmente exigible, son aquellas acciones que hacen coexistir de manera armoniosa lo económico, social y medioambiental. En la empresa VLA se aprecia una sincera voluntad de generar menor impacto ambiental en sus acciones empresariales. Esto se demuestra en que por tercer año consecutivo utiliza biocombustible para reducir sus emisiones de $\mathrm{CO} 2$. Además, por tercer año consecutivo elabora sus reportes de sostenibilidad (GRI). Esto en la práctica le brinda respaldo de la sociedad porque entiende que a través de los últimos años ha buscado ser transparente, responsable con el medioambiente y la sociedad.

\subsection{Entrevistas a especialistas}

Las tres entrevistas a personas prestigiosas y que están ligados al ámbito académico, sector aerocomercial y crisis sirvieron para aclarar mejor el panorama del problema de gestionar la comunicación en momentos de crisis y como salir de la misma.

El profesor Yago de la Cierva afirma que los colaboradores pueden mostrar aprecio por su empresa o realizar el sentido contrario. En ese aspecto asevera que el componente interno de la reputación es decisiva. El componente del clima laboral, satisfacción laboral, etc. mejora la reputación de un importante grupo de interés de la empresa que son los colaboradores. Esto ayuda también a mejorar su employer brand, algo que toda empresa top aspira a llegar para atraer al mejor talento.

Otra idea del profesor Cierva es que en momentos de crisis el grado de vinculación entre la empresa y sus g.i ayuda a que la gente brinde el voto de confianza y la empresa salga de la crisis. Este extracto de su entrevista resume de manera clara la gestión y salida de una crisis:

"Una crisis pone de manifiesto el grado de vinculación que tienen los públicos prioritarios con la organización. Si las relaciones son fuertes y fluidas, la gente dará un

voto de confianza a los gestores y será posible la recuperación. En cambio, si la empresa no tiene lleno el "almacén de benevolencia", la crisis tendrá efectos mucho más negativos, porque será la confirmación de su mala impresión previa. Prevenir las crisis no solo significa evitar los problemas, sino sobre todo robustecer las relaciones con mis grupos de interés".

Lo que nos dice José Salazar - CEO y fundador de Proel, firma especializada en prevención y gestión integral de crisis es que cuando hay muertos o heridos se nos olvida realizar el acompañamiento para los familiares, algo que es importante y en 
algunos casos dejado de lado. Lo mínimo que puede hacer una empresa es brindar ese acompañamiento a los familiares y cerrar el círculo de una manera sana. Haya sido o no culpable de las muertes. Las palabras de José Salazar son las siguientes:

"Se descuida mucho el tema de la familia, cuando hay un herido de gravedad, cuando hay un muerto la institución, la empresa así no haya sido culpable de este tema tiene que facilitar un proceso de acompañamiento para los familiares afectados y muchas veces se descuida ese tema, se deja a la familia sola no se le presta atención y que va a suceder que las familias afectadas van a criticar esto y en definitiva no van a permitir que la crisis disminuya..."

Otra idea a tomar en cuenta que no necesariamente se tiene que contratar una agencia externa de crisis para salir de la misma. Sino que si el equipo de comunicaciones está bien preparado puede asumir la gestión de la comunicación en tiempo de crisis.

El monitoreo de medios en tiempo de crisis es importante y así lo afirma José Salazar:

“...Ahora si detectas que se está desarrollando la crisis tienes que actuar inmediatamente. Lo primero es un monitoreo constante a los medios, segundo acostumbrarse a tener mensajes claves, las empresas tienen que acostumbrarse a tener mensajes claves listos para cualquier situación o eventualidad porque hoy día está demostrado que cualquier empresa en algún momento de su desarrollo de negocios va a enfrentar una crisis..."

En la lectura a la entrevista a Antonio Olortegui rescate la idea de las capacitaciones y simulaciones ante una crisis, lo que me llevo también a aplicarlo en mi propuesta post crisis.

Quiero cerrar las entrevistas a especialistas con esta pregunta a Antonio, en referencia a si habían tenido un accidente con víctimas humanos, a lo que respondió:

“...Nosotros no hemos tenido pero lo que dicen los protocolos es que la reacción es dar la información certera. Lo que el analista tiene que hacer es dar claridad y recién uno se encuentra en la capacidad de hacer un anuncio cuando cuenta que la información es cierta y verificada"

En otras palabras siempre dar información veraz y que sea verificada al 100\%, más aún en tiempo de crisis.

\subsection{Opinión personal}

En resumen ante una crisis con víctimas humanas, lo primero que debe hacer una empresa es mandar el mensaje de empatía y respeto a los familiares de las víctimas. En las conferencias de prensa, mostrarse los más abierta a las preguntas de la prensa, si 
tienen cuestionamientos ante las acciones de la empresa ante la crisis, guardar la calma y nunca pelearse. Tener siempre presente los mensajes a posicionar y que los familiares de las víctimas tengan presente que la respuesta de pésame es sincero y no por buscar solamente salirse del problema.

Otro punto a destacar es que en este tipo de crisis la contratación de un monitoreo de medios ayuda mucho a enfocarse en la respuesta y ya no en recoger información de lo que dicen los medios de la empresa durante la crisis.

Cada crisis es distinta, sin embargo tener un Plan de Crisis con un Gabinete definido y con capacitaciones periódicas para estar preparados, brinda una ventaja frente a aquellas empresas que no se hayan dado el tiempo de planear y elaborar una. Este plan es la hoja de ruta donde se han pensado todas las posibles crisis y cómo salir de ellas. En otras palabras tener un Plan de Crisis es esencial para cualquier empresa, sea pequeña o grande, porque nadie sabe en qué momento llegará la crisis y es mejor estar preparados. 


\section{REFERENCIAS}

Andreu, Alberto; Fernández, José Luis. (2011). De la RSC a la sostenibilidad corporativa: una evolución necesaria para la creación de valor». Ediciones Deusto,

Freeman, R. E, (1984), Strategic Management: A Stakeholder Approach, Boston Pitman,

Remy, Paul, (2015), Manejo de crisis: ¿Qué hacer el día en que todo está en contra nuestra?, Lima - Perú, Universidad de Ciencias Aplicadas.

Solano Cornejo, D, (2009), Responsabilidad Social: Estrategias sostenibles para el desarrollo y la competitividad, Lima - Perú, Esan Ediciones.

Villafañe, J, (2014), La Buena Reputación: Claves del valor intangible de las empresas, Madrid - España, Ediciones Pirámide. 


\section{ANEXOS}

(Documentos complementarios: bocetos, guiones, entrevistas, gráficos, cuadros, etc.)

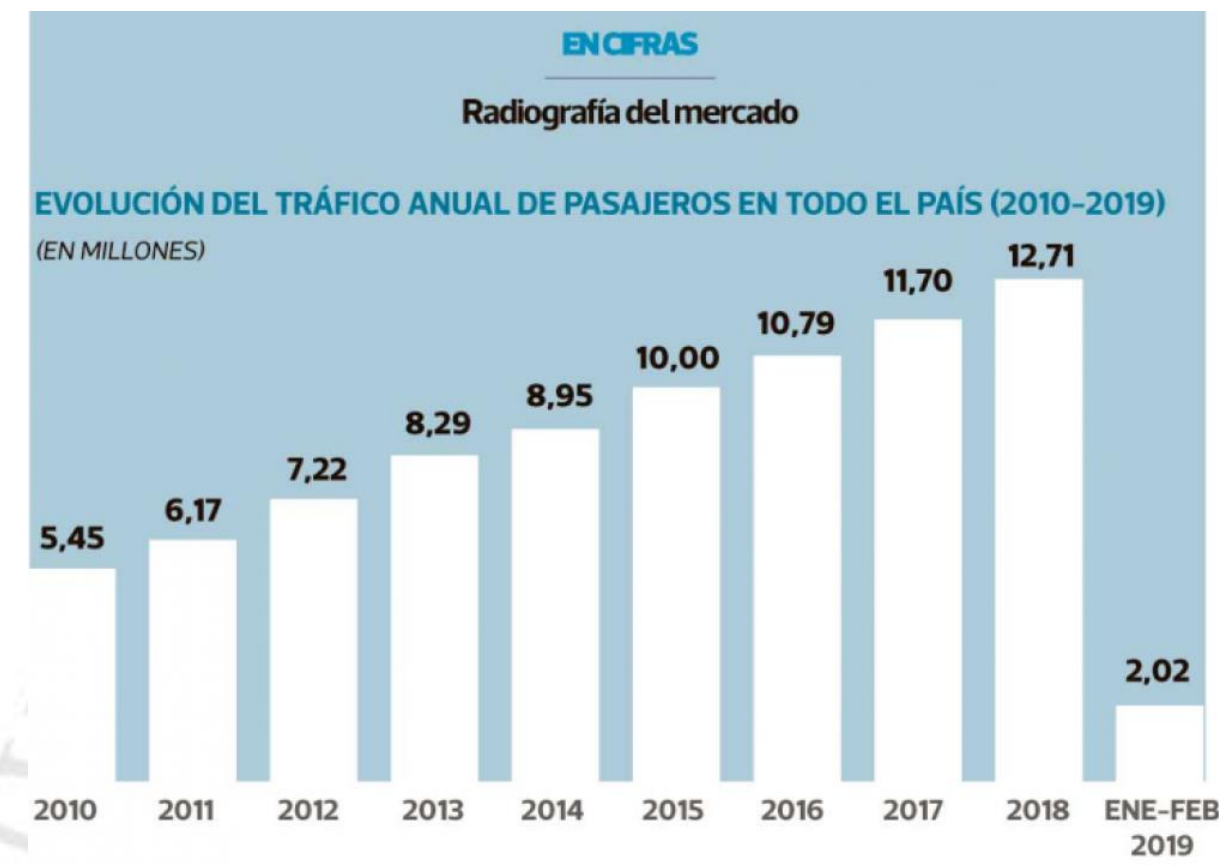

Figura 1 Tráfico anual de pasajeros en Perú (millones)

Fuente: El Comercio

EVOLUCIÓN DEL TRÁFICO ANUAL DE PASAJEROS

EN TODO EL PAÍS SEGÚN LÍNEAS AÉREAS (2010-2018)

\begin{tabular}{|c|c|c|c|c|c|c|c|}
\hline & LATAM & PERUVIAN & AVIANCA & LC PERÚ & $\begin{array}{l}\text { VIVA } \\
\text { AIR }\end{array}$ & $\begin{array}{l}\text { STAR } \\
\text { PERÚ }\end{array}$ & ATSA \\
\hline 2010 & 3'838.112 & 610.347 & 147.390 & 97.773 & & 659.094 & 42.938 \\
\hline 2011 & 3'931.485 & 803.561 & 438.374 & 33.392 & & 838.548 & 63.026 \\
\hline 2012 & $4^{\prime} 488.512$ & 760.015 & 906.733 & 128.095 & & 785.763 & 86.470 \\
\hline 2013 & $5^{\prime} 256.240$ & 880.052 & $1 ' 165.673$ & 255.706 & & 627.172 & 40.970 \\
\hline 2014 & $5^{\prime} 655.413$ & r'089.725 & $1 ' 160.503$ & 280.711 & & 624.680 & 55.331 \\
\hline 2015 & 6'213.918 & 1310.658 & 1265.472 & 474.236 & & 598.928 & 49.207 \\
\hline 2016 & $6^{\prime} 627.050$ & 1344.370 & 1284.324 & 906.144 & & 486.526 & 54.406 \\
\hline 2017 & $6 \cdot 746.867$ & $1 ' 673.558$ & 1'301.109 & 1136.986 & 305.948 & 375.381 & 72.490 \\
\hline 2018 & $7 ' 393.426$ & 1759.122 & $1 ' 246.988$ & 1'004.952 & 797.837 & 320.992 & 89.862 \\
\hline
\end{tabular}

Figura 2 Tráfico anual de pasajeros por línea aérea en Perú (2010-2018)

Fuente: El Comercio 


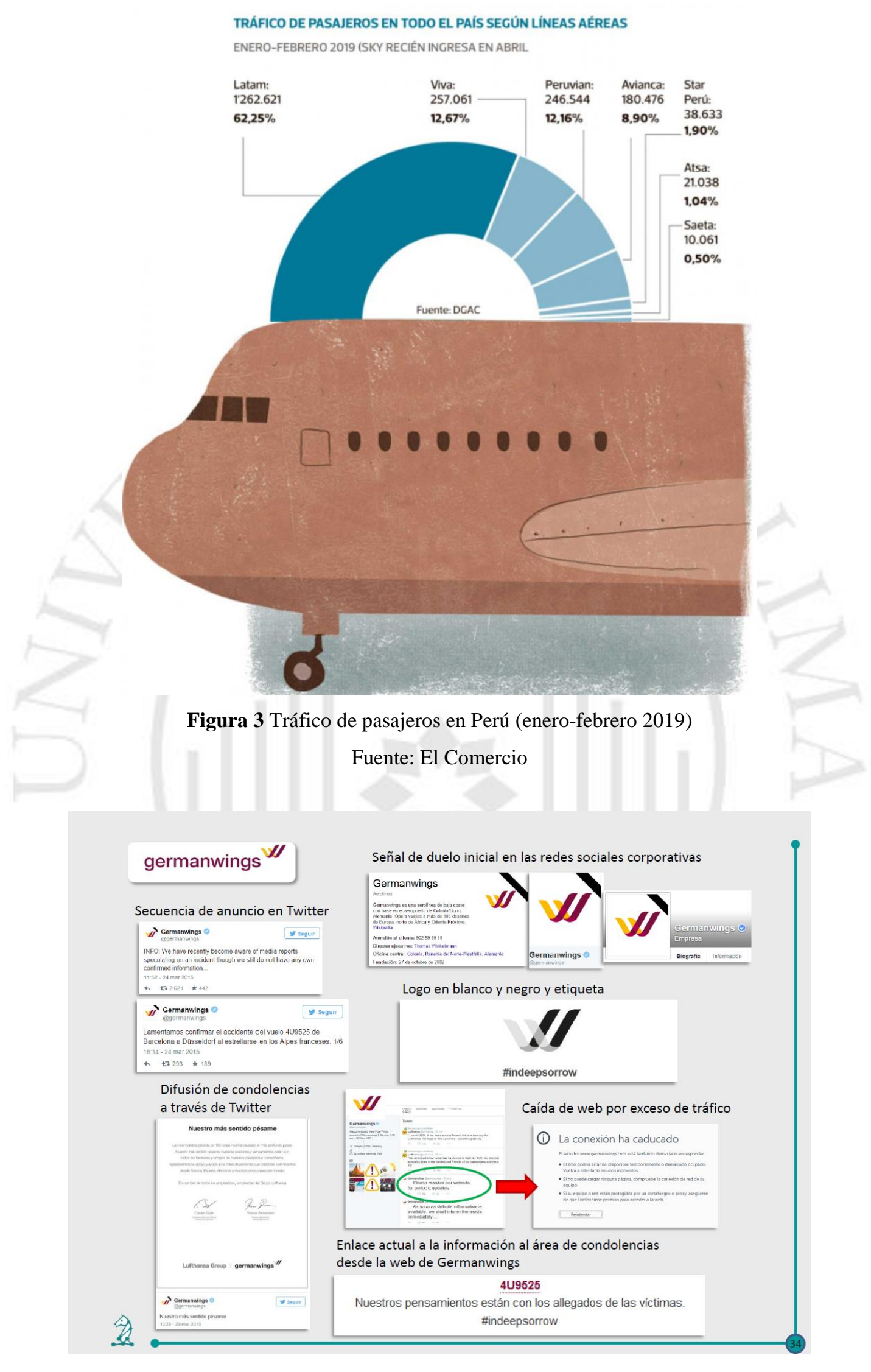

Figura 4 Acciones de comunicación tomadas por la compañía

Fuente: Logic Activity 


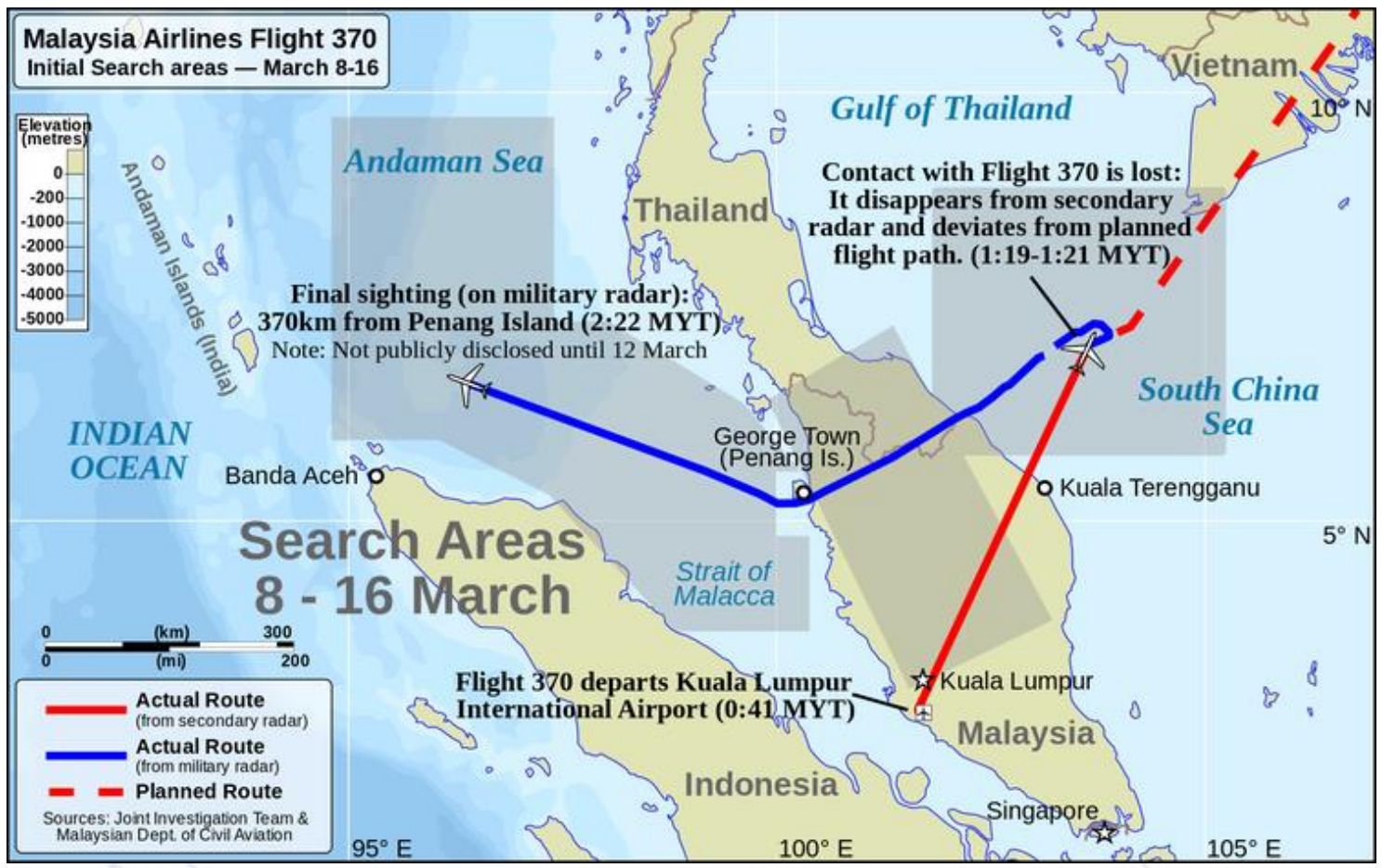

Figura 5 Punto del viraje, la ruta seguida por el MH370 y el área de búsqueda inicial Fuente: (Andrew Heneen/ Shattered Gnome/ Wikipedia)
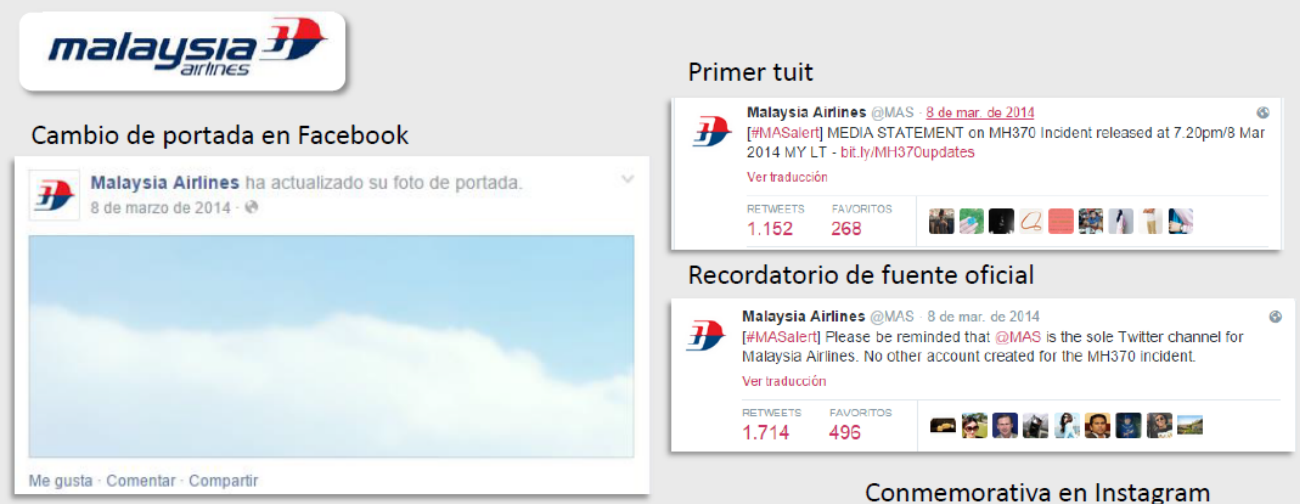

Polémico texto del SMS

7. Malaysia Airlines 24 de marzo de 2014 - Edilado - O

We deeply regret that we have to assume that $\# \mathrm{MH} 370$ ended in the southern Indian Ocean. We humbly offer our sincere thoughts, prayers and condolences to everyone affected by this tragedy -

http://bitily/MH370updates
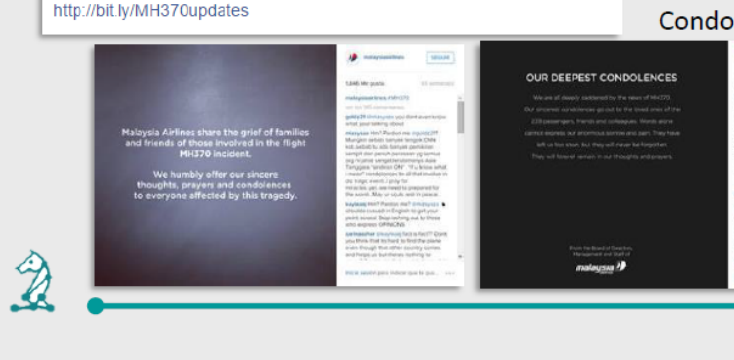

Conmemorativa en Instagram

Figura 6 Acciones de comunicación tomadas por malaysia airlines

Fuente: Logic Activity 


\section{Principales instrumentos internacionales de RSC}

\begin{tabular}{|c|c|}
\hline $\begin{array}{l}\text { Global Compact (enero de } \\
\text { 1999) }\end{array}$ & $\begin{array}{l}\text { Iniciativa voluntaria en la que las empresas se comprometen a alinear } \\
\text { sus estrategias y operaciones con diez principios universalmente } \\
\text { aceptados en cuatro grandes áreas: derechos humanos, estándares } \\
\text { laborales, medio ambiente y anti-corrupción. }\end{array}$ \\
\hline $\begin{array}{l}\text { Dow Jones Sustainability } \\
\text { Indexes }(1999 \text {, revisados en } \\
2010)\end{array}$ & $\begin{array}{l}\text { Son los primeros índices globales que siguen el desempeño financiero de } \\
\text { las empresas líderes en sostenibilidad, para poder entrar en él se deben } \\
\text { cumplir unos requisitos establecidos en base a criterios en económicos, } \\
\text { ambientales y sociales a largo plazo. El volumen de negocio generado en } \\
\text { torno al DJSI es alrededor de } 5.500 \text { millones de dólares. }\end{array}$ \\
\hline $\begin{array}{l}\text { AA1000 Framework (1 de } \\
\text { noviembre de 1999) }\end{array}$ & $\begin{array}{l}\text { Norma desarrollada por el Institute of Social and Ethical Accountability } \\
\text { que comprende un conjunto de requisitos para ayudar a las empresas a } \\
\text { evaluar distintos parámetros de comportamiento encaminados a medir } \\
\text { la responsabilidad de éstas y cómo se integran estos principios en su } \\
\text { actividad diaria con todos los stakeholders. }\end{array}$ \\
\hline $\begin{array}{l}\text { Global Reporting Inicitative, } \\
\text { GRI (junio de 2000) }\end{array}$ & $\begin{array}{l}\text { Institución independiente que crea el primer marco mundial } \\
\text { estandarizado para la elaboración de memorias de sostenibilidad } \\
\text { de aquellas empresas que deseen medir y reportar su desempeño } \\
\text { económico, social y medioambiental. }\end{array}$ \\
\hline $\begin{array}{l}\text { International Standard on } \\
\text { Assurance Engagements } \\
\text { (junio de 2000) }\end{array}$ & $\begin{array}{l}\text { Marco básico para auditorias de gran escala sobre procesos en } \\
\text { materia no financiero-contable. Estas auditorías incluyen aspectos } \\
\text { medioambientales y de sostenibilidad y auditando las memorias de } \\
\text { sostenibilidad, los sistemas de información y control y los procesos de } \\
\text { gobierno corporativo principalmente. }\end{array}$ \\
\hline $\begin{array}{l}\text { Guidelines for Multinational } \\
\text { Enterprises de la OCDE } \\
\text { (1976, revisadas en 1979, } \\
1982,1984,1991 \text { y } 2000)\end{array}$ & $\begin{array}{l}\text { Conjunto de recomendaciones formuladas por los gobiernos a las } \\
\text { empresas multinacionales que operan en o desde de los países } \\
\text { miembros, en materias tales como: empleo, relaciones industriales, } \\
\text { derechos humanos, medio ambiente, transparencia, anticorrupción, } \\
\text { ciencia y tecnología, entre otros, y que constituyen un marco voluntario } \\
\text { de principios y estándares para la empresa responsable. }\end{array}$ \\
\hline $\begin{array}{l}\text { Declaración tripartita de } \\
\text { principios sobre las empresas } \\
\text { multinacionales y la politica } \\
\text { social de la OIT (noviembre } \\
\text { de } 1977 \text {, addendum I en } \\
\text { noviembre de } 2000 \text { y marzo de } \\
2006 \text { y addendum II en marzo } \\
\text { de } 2000 \text { ) }\end{array}$ & $\begin{array}{l}\text { Es el primer documento elaborado exitosamente por la Organización } \\
\text { Internacional del Trabajo aplicable universalmente en materia de } \\
\text { empresas multinacionales. Apunta a alentar la contribución positiva que } \\
\text { las empresas multinacionales ejercen sobre el progreso económico. }\end{array}$ \\
\hline $\begin{array}{l}\text { Libro Verde de la Unión } \\
\text { Europea (18 de julio de } 2001 \text { ) }\end{array}$ & $\begin{array}{l}\text { Este libro constituye la materialización del compromiso de la Unión } \\
\text { Europea a favor de la RSE. Mediante un comportamiento socialmente } \\
\text { responsable, las empresas pueden desempeñar un papel esencial para } \\
\text { favorecer que la UE avance hacia su objetivo de mayor crecimiento } \\
\text { económico, competitividad, justicia social y desarrollo sostenido. }\end{array}$ \\
\hline $\begin{array}{l}\text { ISO } 26000 \text { (16 de septiembre } \\
\text { de 2010) }\end{array}$ & $\begin{array}{l}\text { Es la guía que establece las líneas en materia de responsabilidad social } \\
\text { establecidas por la Organización Internacional para la Estandarización. } \\
\text { Su objetivo principal es ayudar a las organizaciones a establecer, } \\
\text { implementar, mantener y mejorar los marcos o estructuras de RS. }\end{array}$ \\
\hline
\end{tabular}

Figura 7 Principales instrumentos internacionales de RSC

Fuente: "De la RSC a la sostenibilidad corporativa: una evolución necesaria para la creación de valor». (C) Ediciones Deusto. Referencia n. ${ }^{\circ} 3876$ 


\section{Entrevistas}

Entrevistado: Yago de la Cierva, Docente Internacional de la Maestría en Comunicación Estratégica de las Organizaciones de la Universidad de Piura. / Profesor del IESE.

Tema: Reputación corporativa y manejo de crisis

Para los recién iniciados en temas de Comunicación. Hay tres conceptos que resultan confusos: Imagen, Identidad y Reputación. ¿Cuál sería su definición para cada uno de ellos?

No me extraña que se dé cierta confusión, porque son conceptos muy cercanos y las fronteras son difusas. Para mí, imagen es el aspecto más superficial y externo de la empresa; la identidad es el conjunto de principios, valores y prácticas (cultura institucional) de una organización; y la reputación, las percepciones sociales respecto a la identidad y a las actividades de esa organización, basadas en experiencias propias o ajenas, que conducen a una recomendación.

¿Cuál considera que sea el grado de influencia entre el clima laboral y la reputación empresarial? ¿De qué forma se manifiesta en la reputación?

El clima laboral es un índice, más o menos profundo, de la unión de los empleados con su empresa. Cuando se ha medido con rigor, refleja bien esa unión; de lo contrario, puede manifestar principalmente situaciones transitorias. En cualquier caso, la componente interna de la reputación es decisiva: los empleados irradian aprecio e información por su empresa, o lo contrario.

Los valores empresariales están siempre ligados al giro del negocio (core business) de la empresa. Por ejemplo, los valores empresariales de Volvo son: Calidad, seguridad y cuidado del medio ambiente. ¿Qué sucede cuando uno de los valores que tiene la empresa no se cumple? ¿Cómo afecta en la Reputación?

Depende del grado de discrepancia entre la realidad y lo que se proclama, y de qué gravedad tenga para los públicos prioritarios esa incoherencia.

Repregunta: ¿Qué acciones puede tomar la empresa para potenciar ese valor no cumplido y qué papel juega la comunicación en ese aspecto?

Si existiera una discrepancia entre la identidad proclamada y la realidad diaria, lo importante es regenerarse y volver a los principios institucionales. La comunicación acompaña y ayuda, pero estamos ante un problema de gobierno, no de comunicación. 
Cuándo se realiza un mapeo de grupos de interés, evidentemente no todos los G.I son iguales y tienen diferentes intereses hacia la empresa. ¿Se puede tener mayor 0 menor reputación empresarial de acuerdo a cada grupo de interés? o ¿La reputación es algo transversal a todos los grupos de interés y se tiene casi la misma reputación empresarial para todos los GI?

Cada grupo de interés tiene conocimientos, experiencias y expectativas distintas, y por tanto es posible que unos colectivos se sientan muy involucrados y apoyen a la organización, y otros menos, o incluso nada. Precisamente por eso, una tarea fundamental de la organización es integrar esas relaciones y procurar que todos los g.i. aprecien la organización por lo que es, y depositen en ella su confianza.

Cuando se mide la reputación de empresas ligadas a sectores competitivos como el aerocomercial, donde un accidente con víctimas fatales puede ser el punto de quiebre de su reputación. ¿Cómo puede una buena gestión de la Responsabilidad social ser un escudo frente a momentos de crisis, por ejemplo, un accidente de avión?

Una crisis pone de manifiesto el grado de vinculación que tienen los públicos prioritarios con la organización. Si las relaciones son fuertes y fluidas, la gente dará un voto de confianza a los gestores y será posible la recuperación. En cambio, si la empresa no tiene lleno el "almacén de benevolencia", la crisis tendrá efectos mucho más negativos, porque será la confirmación de su mala impresión previa. Prevenir las crisis no solo significa evitar los problemas, sino sobre todo robustecer las relaciones con mis grupos de interés. 


\section{Entrevistado: Antonio Olortegui - Gerente Central de Asuntos Corporativos, Legal, y Compliance de Latam Airlines Perú.}

Tema: Seguridad aerocomercial y manejo de crisis

¿Cómo ven la competencia en torno al Low Cost? ¿Cuán seguro es? ¿Cómo han manejado el Low Cost en el plano comercial y de comunicación con sus clientes?

Efectivamente nosotros ya veíamos que hace un par de años y un poquito más el fenómeno Low Cost no era algo propio de la región de Sudamérica ni Latinoamérica sino que era un fenómeno global. De hecho algunos ejecutivos del holding de la empresa viajaron a ver como se comportaban este fenómeno en Europa y Asia y llegaron con muchas ideas y hace un par de años nos preparamos también para esta nueva tendencia y centralizamos estos llamados plan de church que son bandejas de tarifas con lo que el público necesita. Un público que solo necesita solo transportarse tiene una opción barata, un público que quiere transportarse con una maleta tiene otra opción, un público que quiere transportarse con una maleta y quiere acumular millas tiene otra opción, un público que no solo quiere transportarse sino que quiere tener el beneficio o atributo de poder cambiarlo en cualquier momento y le reembolsen el ticket tiene otra opción. Entonces creo que como empresa nos preparamos bastante bien a esta tendencia, hoy por hoy es una realidad que está acá en Perú, competidores de esa naturaleza. Bienvenida la competencia a su vez como empresa fuimos responsables en prepararnos con esta tendencia que ya vino al Perú y se viene manejando en el mundo.

Sabes que vas a encontrar tarifas por tramo en LATAM por doce dólares que incluye la TUA e impuestos aeroportuarios es decir precio al pasajero. Por lo expuesto, considero que, el trabajo de cambiar ¿cómo ofrecemos nuestro producto? y ¿qué ofrecemos? Va beneficiar al público sobre todo en el tema del ahorro de costos.

¿Las ofertas que se facilitan en Low cost son seguras? ¿Las ofertas son monitoreadas por LATAM?

Yo no puedo hablar por otras aerolíneas $u$ otros operadores, en realidad cada uno maneja sus propios estándares de seguridad en todos sus segmentos pero en LATAM hace algunos años atrás no tiene en supuesto la disminución en absoluto de los estándares de seguridad. Ese tema para nosotros es el paso cero antes de cualquier decisión que queramos tomar, si es que una decisión involucra una disminución o el riesgo de seguridad operacional es una alternativa que no vemos, no lo ponemos en juego como te comento es el paso cero para cualquier proyecto o alternativa y ese es un intransable en nosotros. No te puedo responder por otros operadores pero si ten la seguridad y la garantía que por LATAM se valora la seguridad operacional. 
¿Cuál es la relación del Compliance o asuntos corporativos con la seguridad en LATAM?

Así como nos hemos puesto los más altos estándares en términos de seguridad tuvimos también una proclamación hace tiempo de tener los estándares en temas de Compliance instaurando políticas que tanto el público como los trabajadores la interioricen y ejecuten. Estas políticas se vienen dando años atrás. A su vez, hoy tenemos un canal de ética interno como también podemos recibir denuncias externas y anónimas generando así una cultura de Compliance y buen gobierno corporativo también creemos que contribuimos a que la empresa tenga una buena reputación y sea un diferencial así al momento de elegirnos.

¿Cuál fue la respuesta de LATAM ante un incidente? ¿Cuentan con un plan de crisis? Coméntenos un poco por favor si hubieran tenido recientemente un problema de este tipo.

Nosotros contamos con un plan de emergencia y contingencia ante este tipo de eventos, se activa unos protocolos especiales los cuales no solamente nos capacitamos en tenerlos refrescados sino también en hacer simulaciones. En realidad si tenemos ese plan de contingencia o emergencia sobre la mesa con las respectivas vocerías de ser el caso.

Claro, es una mesa donde intervienen no solamente su área sino otras áreas del negocio.

Es una mesa multidisciplinaria pueden intervenir comunicaciones externas, legal, recursos humanos, diversas áreas del área comercial que lo que buscan es tomar decisiones inmediatas es decir rápidas y eficientes, si contamos con ese plan y tratamos de practicarlo haya o no haya ese evento para saber cómo reaccionar ante alguna de esas eventualidades.

¿Cuánto tiempo estiman que se debe reaccionar ante un incidente o de pende del caso?

Depende del caso, si es un incidente mayor o menor. Es muy casuístico así que partimos de los parámetros generales y vemos en que supuesto estamos para poder saber la conducta que debemos seguir al respeto.

¿Cómo actuarían en un accidente que involucre perdidas de vida?

Felizmente, nosotros no hemos tenido pero lo que dicen los protocolos es que la reacción es dar la información certera. Lo que el analista tiene que hacer es dar claridad y recién uno se encuentra en la capacidad de hacer un anuncio cuando cuenta que la información es cierta y verificada. 
Después de esto empezar actuar, obviamente considerando una empresa como LATAM que tiene todas estas políticas, tiene claro el tema de Compliance y temas corporativos siempre va estar adelante.

Sí, claro que sí y tratando de seguir estándares que a nivel mundial no sé si decir exitosos porque uno nunca sabe cómo va reaccionar; pero por lo menos tratar de seguir los mejores estándares que se presenta en la industria

¿Consideras que tener una adecuada política de Sostenibilidad y que intervenga el tema de Compliance ayuda o contribuye a tener más claro todas las gestiones comunicacionales y saber actuar en este tipo de escenarios de manera más eficiente? ¿Existe un tipo de relación en este aspecto?

Sí, yo creo que sí. Porque si te fijas Compliance es el tema del cumplimento y procedimientos internos y políticas y código de ética. Lo que estas generando en la cultura Compliance el personal, los colaboradores y todos se involucren todo lo que está escrito y con los manuales que existen al respecto, entonces definitivamente si tú tienes una cultura de Compliance vas a generar ante posibles eventualidades es que las personas se comporten y reaccionen como está escrito en estas políticas. Entonces si tienen una relación directa ya que no se improvisa ante esos momento o se reacciona emocionalmente sino lo que se te invita hacer es revisar lo que has ensayado, lo que ha establecido las políticas respectivas que ayudan en esos momentos de crisis.

¿Salvaguardando la reputación de la empresa?

No creo que el motivo sea la reputación sino es una consecuencia. Si procedes conforme se ha establecido el día que ocurra un supuesto y tú ejecutes la consecuencia que está establecida está dará mayor credibilidad y no solo por un cumplimiento legal ante las autoridades aeronáuticas sino que te da mayor credibilidad ante el mercado. 


\section{Entrevistado: José Salazar - CEO y fundador de Proel, firma especializada en prevención y gestión integral de crisis.}

\section{¿Cuáles son las características imprescindibles para darnos cuenta que estamos en una crisis a nivel organizacional? \\ Característica numero 1:}

Hoy día hay un nuevo elemento que se ha incluido dentro de las variables que tenemos para saber si una empresa o una institución o una sociedad están en crisis o no. Definitivamente decíamos que si había impacto en los medios de comunicación, en la radio, en la televisión, mencionándonos varias veces entonces era porque nuestro nombre, nuestra reputación estaban siendo criticados. Hoy en día con la aparición de las redes sociales es un poco más difícil, en qué momento sabes que estas en un proceso de crisis porque una sugerencia o un comentario no necesariamente te puede generar una crisis sin embargo si tú no lo monitoreas bien sino asumes tú propio registro y sobre todo interpretación, puedes dejar que este comentario o sugerencia en Facebook se convierta en una crisis.

Característica numero 2:

Estamos en crisis cuando existen heridos o muertos, porque no se puede aceptar que haya una situación de muerte o heridos.

Característica numero 3:

Cuando se ve afectado el tema medioambiental, el tema medioambiental hoy día es un tema muy sensible. Entonces ya no se permite que una empresa pueda afectar el tema medioambiental. Un derrame, un incidente medioambiental, todos esos temas que constituyen una crisis porque vas a ser muy criticado, los supervisores van a poner una multa y eso afecta tú nombre y reputación.

En esos 3 casos cuando te paraliza la población con el tema que tengas un muerto o herido. Cuando has impacto en temas medioambientales estos o te encuentras en una crisis. Ahora explicado en términos generales, pero también hay que ver cada caso de forma específica porque todas las empresas son distintas, el impacto en la sociedad son distintos teniendo en función su público objetivo.

Entonces mencionaste el tema, cuando hay accidentes o muertes, el tema medioambiental y ¿El primero cuál era?

El primero es cuando tú operación se ha detenido 
En el caso de pérdida de un ser querido. Cuando en un accidente se ha originado muerte ¿Cuáles serían los pasos para tomar, para hacerle frente a la crisis porque estamos hablando de pérdidas humanas?

Se descuida mucho el tema de la familia, cuando hay un herido de gravedad, cuando hay un muerto la institución, la empresa así no haya sido culpable de este tema tiene que facilitar un proceso de acompañamiento para los familiares afectados y muchas veces se descuida ese tema, se deja a la familia sola no se le presta atención y que va a suceder que las familias afectadas van a criticar esto y en definitiva no van a permitir que la crisis disminuya. Un familiar que está herido o un familiar muerto es un gran dolor para una familia lo que se sugiere es siempre que atender a través de un experto en familia, las empresas en una situación de crisis no tienen que ponerse tacaños como yo les digo, hay que destinar inmediatamente recursos para poder atender esta situación crítica; si es con familias con mucha mayor razón.

¿Qué se debe hacer en materia de comunicación? En estas situaciones la prensa sale, la reputación se ve comprometida. ¿Qué acciones tomar?

La redes hoy en día nos ha puesto en una situación mucho más vulnerable, lo que antes podíamos tardarnos un tiempo para responder en la prensa, la televisión y la radio podías tomarte hasta horas. Imagínate antes en la prensa había una crisis y tenías que esperar que el periódico se publique; ahora la publicación es en minutos. Ahora si detectas que se está desarrollando la crisis tienes que actuar inmediatamente. Lo primero es un monitoreo constante a los medios, segundo acostumbrarse a tener mensajes claves, las empresas tienen que acostumbrarse a tener mensajes claves listos para cualquier situación o eventualidad porque hoy día está demostrado que cualquier empresa en algún momento de su desarrollo de negocios va a enfrentar una crisis; ahora tú debes de asumir que en algún momento te va a tocar por lo que si sabes que te va a tocar tienes que trabajar mucho la prevención.

\section{Anticiparse a estos escenarios que se pueden dar}

Exactamente.

Ahora tocando un poco el tema de responsabilidad social, de qué forma si es que hablamos de una empresa socialmente responsable pero que ha pasado esta situación de crisis. ¿Qué relación existe? ¿Ayuda la RS ahí? ¿Una empresa que ha trabajado en estos temas, ¿cómo lo ve usted?

Sin duda hoy en día las empresas que actúan bajo el sombrero de la responsabilidad social son genuinas les va importar este tema, va hacer como un elemento más en su tablero de escenarios de riesgos que tienen que cubrir. Así como las empresas se preparan para impactar menos en el tema medioambiental o en el tema social como algunas actitudes de la empresa o del equipo que forma la empresa también pueden afectar en la reputación. 
Pongo un caso, hoy día estoy yendo a ver un caso de acoso sexual dentro de la propia empresa que se constituyen en situaciones de crisis. Estoy viendo empresas que no despiden o que no se desvinculan bien de sus trabajadores, de sus gerentes sobre todo están pasando por situación de crisis, estoy viendo como empresas que no manejan el tema de igualdad de género también se constituyen en situaciones de crisis, porque los trabajadores hoy en día se han vuelto mucho más críticos de sus propias empresas entonces te pueden criticar, pueden criticar a su propia empresa, esto genera que la empresa tenga que cuidar mejor a sus stakeholders internos y quienes son los que le dan una mayor atención a sus stakeholders, pues son las empresas que tienen una actitud más seria hacia la responsabilidad social.

¿Es conveniente contar con un comité de crisis o contratar una agencia externa especialista en crisis? Usted en su calidad de consultor ¿Cómo percibe ese escenario.

A ver, los dos temas no son excluyentes, tú puedes si tienes un buen equipo de comunicaciones y si tú equipo está preparado, tienes tus mensajes, tienes mapeados tus escenarios de riesgos, tienes respuestas para cada escenario de riesgos obviamente tú puedes ir a gestionar adecuadamente la crisis pero si no tienes nada de eso vas a tener que acudir a los expertos. Mi recomendación es, primero fortalezcamos los equipos internos, no solamente de comunicación - haciendo la salvedad- A los gerentes, a los voceros tienen que tener mucha capacitación para saber cómo van actuar en situaciones de crisis y lamentablemente tienen que enfrentar a una situación bastante crítica. Si es asi pueden recurrir a una agencia que les pueda apoyar porque nosotros muchas veces estamos en el día a día bajo mucha presión, bajo el estrés de una crisis es mejor un apoyo externo que no solo te traiga el conocimiento sino también la metodología y la calma que muchas veces en una situación de crisis el comité de crisis pierde la calma. Ahora es indispensable que toda empresa tenga un comité de crisis ya formado y no solamente formado sino capacitado, que haga entrenamiento para una eventual situación de crisis a la que puedan enfrentar. 